University of Louisville

ThinkIR: The University of Louisville's Institutional Repository

Electronic Theses and Dissertations

$12-2011$

\title{
Noir ontology : existing in the fragmented spaces of Los Angeles.
}

Jacob Andrew Goessling

University of Louisville

Follow this and additional works at: https://ir.library.louisville.edu/etd

\section{Recommended Citation}

Goessling, Jacob Andrew, "Noir ontology : existing in the fragmented spaces of Los Angeles." (2011). Electronic Theses and Dissertations. Paper 507.

https://doi.org/10.18297/etd/507

This Master's Thesis is brought to you for free and open access by ThinkIR: The University of Louisville's Institutional Repository. It has been accepted for inclusion in Electronic Theses and Dissertations by an authorized administrator of ThinkIR: The University of Louisville's Institutional Repository. This title appears here courtesy of the author, who has retained all other copyrights. For more information, please contact thinkir@louisville.edu. 
NOIR ONTOLOGY:

\title{
EXISTING IN THE FRAGMENTED SPACES OF LOS ANGELES
}

\author{
By \\ Jacob Andrew Goessling \\ B.A., University of Louisville, 2007
}

\begin{abstract}
A Thesis
Submitted to the Faculty of the

College of Arts and Sciences of the University of Louisville

In Partial Fulfillment of the Requirements

For the Degree of
\end{abstract}

Masters of Arts

Department of English

University of Louisville

Louisville, Kentucky

December 2011 
Copyright 2011 by Jacob Andrew Goessling

All rights reserved 


\section{NOIR ONTOLOGY:}

\section{EXISTING IN THE FRAGMENTED SPACES OF LOS ANGELES}

By

Jacob Andrew Goessling

B.A., University of Louisville, 2007

A Thesis Approved on

November 30, 2011

By the following Thesis Committee:

Aaron Jaffe (Thesis Director) 


\section{ACKNOWLEDGEMENTS}

I would like to thank my committee for devoting their time and energy during the process of writing this thesis. I especially extend my gratitude to Aaron Jaffe for his encouragement and expertise throughout my undergraduate and graduate work. Most of all, I would like to thank my parents, whose endless support during the process of writing has made this project possible. 


\section{ABSTRACT \\ NOIR ONTOLOGY: EXISTING IN THE FRAGMENTED \\ URBAN SPACES OF LOS ANGELES \\ Jacob Goessling}

November 30, 2011

Noir Ontology: Existing in the Fragmented Urban Spaces of Los Angeles explores the role of decentered urban geography within the body of noir texts set within Los Angeles. By focusing on the development of the idea of Los Angeles in early to midTwentieth century literature and film, this essay argues that Alain Badiou's system of ontology provides a critical apparatus for investigating the many ways in which the Los Angeles sunshine myth organizes the relations between individuals within particular urban spaces. Through an analysis of the city's early cultural history, Roman Polanski and Robert Towne's film Chinatown, and Chester Himes's novel If He Hollers Let Him Go, this project develops the concept of an LA noir ontology that expresses a suspicion towards post-industrial urban development and the modifications that it makes to everyday life while echoing Badiou's contemporary critique of the role capitalism in contemporary globalized society. 


\section{TABLE OF CONTENTS}

PAGE

ACKNOWLEDGEMENTS ..............................................................

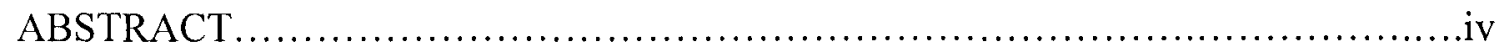

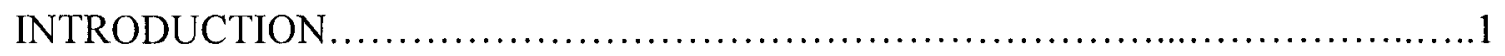

CHAPTER 1: NOIR AS THE LOS ANGELES ANTI-MYTH........................12

CHAPTER 2: CHINATOWN AND THE WORLDING OF LA............................34

CHAPTER 3: IF HE HOLLERS AND THE MINIMUM OF APPEARANCE............52

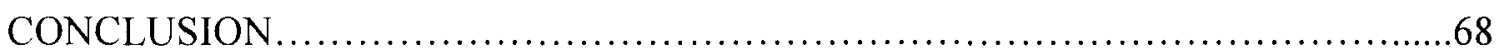

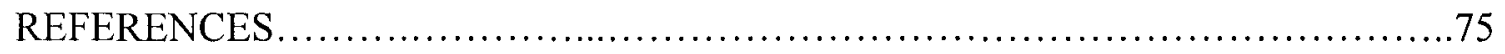

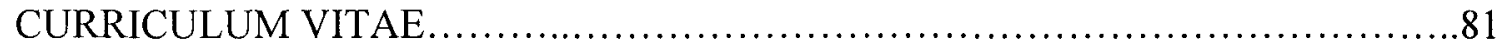




\section{INTRODUCTION}

"Real cities have something else, some individual bony structure under the muck."

-Philip Marlowe, The Little Sister (1949)

"The more carefully one examines space, considering it with the eyes, not only with the intellect, but also with the senses, with the total body, the more clearly one becomes aware of the conflicts at work within it..."

-Henri Lefebvre (1974)

Since the publication of Carey McWilliams's 1946 study Southern California

Country: An Island on the Land, Los Angeles has held a critical position in the theoretical investigation of $20^{\text {th }}$ century urban life. Billed as the city of the future in the last decades of the $19^{\text {th }}$ century, Los Angeles represents the emergence of a new form of the city neither tethered to industrial production nor developed around a dense preexisting urban core. Instead, Los Angeles exists as a sprawling city of conspicuous consumption, populated by office workers, clerks, intellectuals, and multiple generations of wealthy elite. The process of modernization - still very much active in most US cities during the early half of the century - appeared nearly complete early in LA's history as the blank canvas of Southern California provided opportunities to develop new modes of urban living without having to remove any residue from the industrial age. With knowledge of past life unable to translate into Los Angeles's urban space, much of the city's early literature and film concerned itself with the effects that these changes had on modern urban existence. The modernist suspicions of industrial technology, liberal democracy and rational certainty undergird much of LA's early cultural production as individuals 
struggled to understand how to relate to the spaces they inhabited. While much of postEnlightenment scientific thought preoccupied itself with the task of "knowing" the city, Los Angeles proved uniquely unknowable to many of its inhabitants. Thus, Los Angeles literature and film expresses a profound anxiety over the mystery inherent to the city's very structure.

Los Angeles, like every city, is a nexus of connections. By minimizing the separation between people, products, and production, cities facilitate a level of interaction that would not otherwise be possible, and as a result these environments offer "exponential connections among people" which "breed innovation, the production of more and better knowledge" (Walker par. 2). While the logic of connection is present in any urban environment, the twentieth century is marked by significant changes in how cities are organized, and no city has come to symbolize these changes more than Los Angeles, the paradigmatic sprawling metropolis and the first city to construct a freeway system. The growth of Los Angeles ushered in a new experience of living in urban space as the car speeding down the freeway replaced the flaneur's leisurely stroll through a crowded downtown street. As a result, individuals perceived space in entirely new ways. Los Angeles, as Richard Weinstein notes, is "experienced as a passage through space, with constraints established by speed and motion, rather than the static conditions of solids, of buildings that define the pedestrian experience of traditional cities" (35). At the turn of the $20^{\text {th }}$ century, already established metropolises such as London, Paris, and New York already appeared antiquated, representative of a form of life prior to the new experience of speed. In direct contrast, Los Angeles had little prior history of dense urban development therefore growth exploited the future possibilities enabled by these 
new defining features of urban life. By extension, literature and film set within Los Angeles during this period of growth explores how these features were changing the relationship between city dwellers and the physical space around them.

Los Angeles epitomizes this new logic of development earlier and more drastically than cities that would follow similar patterns of growth because of its particular origins at the endpoint of westward expansion. While the major US metropolises of the 1800 s brought together immigrant labor and industrial production within a centralized urban space controlled by $19^{\text {th }}$ century power politics, the city appeared as a blank slate to those who controlled its early growth. Los Angeles became the embodiment of the capitalist impulse undergirding expansionist ideology, a belief that "man must dominate his environment, impose his will upon nature and the land, and turn that control into wealth" (Lehan 29). Between 1870 and 1900, Los Angeles was flooded with over 230,000 new settlers predominantly from the Midwestern United States, most of whom were white Protestants attracted to the Mediterranean landscape filled with vineyards and orange groves (Soja and Scott 4). Southern California appeared as an Eden for these migrants - a place of endless summer, clean dry air, and fertile soil. Development speculation boomed, and land was bought up and turned into real estate or farmland. Meanwhile, the discovery of oil led to additional population growth and financial investment until the depression years of the 1930s (Davis 116). By 1920, the population had easily surpassed one million people, all spread throughout the previously small towns that merged into the budding Los Angeles metropolis (Soja and Scott 3). For a population base largely familiar with Midwestern rural life, dense urban space represented the European evils that caused American vice, "compel[ing] them to retreat 
to outskirts uncontaminated by urban vices and conducive to rural values" (Fogelson 145). However, the influx of Japanese, Mexican and African-American minorities threatened this depiction of idealized life, a depiction that to this point was white, so newcomers were perpetually trapped in an outward flight (146). At the same time, an economic elite of real estate developers and investors quietly established a power structure that would shape Los Angeles through the first half of the $20^{\text {th }}$ century.

The widespread feeling of isolation caused by Los Angeles's developing urban landscape was magnified by the failure of its Boosters to meet the economic expectations of the middle class, a secondary problem that backgrounds the city's early cultural productions. From the hard-boiled fiction of the twenties and thirties through the height of film noir in the forties and fifties, many writers and filmmakers reacted to the image of Los Angeles manufactured by the city's promoters in order to depict the city as a place overwrought with anxieties over achieving success in post-industrial urban life. Social theorist Mike Davis characterizes the opposition between the promises of a new future and the actualization of that future - between myth and reality-in fictional representations of Los Angeles as one between sunshine and noir. While the term noir originates from the French description of a particular style of film, it has been used by Davis and other critics to denote a critical vision of urban life formed by the constellation of political, economic and social relations that structure Los Angeles. In the original context, found in Panorama du film noir americain, Raymond Borde and Etienne Chaumeton describe the concept of noir as the expression of "a psychological and moral disorientation, an inversion of capitalist and puritan values" that creates a "feeling of discontinuity" (Naremore 22). Likewise, film scholar James Naremore characterizes noir 
as the assimilation of the themes of European high modernism into American popular culture, displaying a preoccupation with "urban landscapes, subjective narration, [and] nonlinear plots" while holding a critical spotlight to "rationalism, industrial technology, and liberal or social democracy" (7). While Los Angeles has always been loosely associated with noir because of the presence of the studios that produced so many films noir and the preponderance of noir texts, Mike Davis's City of Quartz rearticulates the term as a critical construct for thinking about Los Angeles in particular. Davis argues that the dialectic between sunshine and noir offers a vision of Los Angeles as a place where economic and political stratification keep most people from obtaining any semblance of the idealized LA life. Recent studies have concentrated on the role that urban geography plays within LA noir fiction by using the fragmented urban space of Los Angeles to show how noir depictions of the city "capture the pathologies of living in increasingly close confines, with an environment perhaps as much mythologized as paradise slipping away from the middle and lower class" (Hausladen and Starrs 65). ${ }^{1}$ By combining the social critiques found in LA noir texts with the city's unique geography and history, the term noir develops from a loosely defined category of film into a critical expression an individual's being within the many worlds that make up the fragmented metropolis of Los Angeles.

Noir representations of Los Angeles are preoccupied with the experiences of isolated characters as they move through the mysterious spaces that make up the new post-industrial city. As these individuals travel through the city, the spaces they encounter appear qualitatively different than the familiar spaces of the dense urban core, from the faux architecture of a city built to be presented instead of lived in to the isolated

\footnotetext{
${ }^{1}$ For a full discussion of recent noir scholarship among urban geographers, see Farish.
} 
apartment buildings, storefronts and offices of a white collar middle class population. The move away from the developmental logic of close connection brought an altogether new experience that was very different than that of concentrated urban space, initiating a new city of the future disconnected through automobiles, the freeway system, and sprawl. Furthermore, the resulting boundaries within the city turn its landscape into a mosaic of locales, each developing its own specific way of being within the larger context of Los Angeles. However, within each fragment, Los Angeles as an idea still fills the social imaginary; the original sunshine myth is as much a part of the cultural makeup of Los Angeles as the noir critique to which it responds. While Los Angeles as an idea can be understood by looking at the rhetoric that is responsible for the city's growth, an individual's relationship to the fragmented urban space that surrounds them can be explained through an investigation into the importance of ontology in the city's literature and film.

The revelation that the quest to gain knowledge about the city and its operations as a whole is impossible in this new environment characterizes noir literature and film set in Los Angeles, and as a result these texts reveal a line of ontological questioning focused on making sense of one's individual position within the social, political, and economic structures depicted through noir. Within this new form of environment, individual bodies relate to each other as well as the objects that surround them through a complex system that orders existence based on their particular location in space. The French philosopher Alain Badiou provides critical insights on how these structures impact the being of individuals within fragmented urban space by developing an understanding of the term 'world' that is grounded in the existence of an infinite number of worlds that bind together 
objects within a particular space. In Logics of Worlds, Badiou argues that each world has its own order structure that is a transcendental truth in that particular world. ${ }^{2}$ This truth is not universal, but reflective of the dominant ideology within that world; the transcendental is "entirely immanent to the objective configuration of that world" (Hallward Badiou, 111). When one is within a world, one's appearance in that world is ordered according to one's identity with this truth. Each world has its own order structure that "allows us to make sense of the 'more or less' of identities and differences in a determinate world" (Badiou LoW118). For Badiou, existence is a quality of being, and can be measured by relative intensity; a physical body appears in space, but its existence is determined by its identity with the transcendental truth of the world (Hallward Badiou 109). Moreover, a body moving between worlds causes one's appearance to change constantly within fragmented urban space--an action as simple as crossing into a new neighborhood can completely change one's appearance within that world as the order structure changes for each individual space.

Beings within each of these worlds are granted various levels of appearance due to their relation - this is Badiou's logic of worlds:

The logic of a world ... affect[s] a being with a variable degree of identity to other beings of the same world. This requires that in the situation there exist a scale of these degrees - the transcendental of the situation-and that every being is in a world only to the extent that it is indexed to this transcendental (LoW 119).

The transcendental order structure of a world is the "protocol of response" to judging the level of identity that beings have within a world. Badiou divides "inconsistent multiples" - a term which includes individual human beings as well as matter and ideas-into three categories: disjoined multiples, conjoined multiples, and the envelope.

\footnotetext{
${ }^{2}$ Badiou's use of the term truth here is closer to the term fidelity, or "to be true to."
} 
The level of appearance of multiples is determined by the relation between multiples and the transcendental order structure. Disjoined multiples are "slightly above the minimum of non-existence," while conjoined multiples are those multiples whose appearance is stable due to the relationship between beings within the world (Shaw 436). The envelope is "the worldly multiple that guarantees the regional stability of all beings, whether conjoined or disjoined, through its maximal value of appearance that subsumes all others" (Shaw 436). The envelope can be understood as the social institutions that enforce order upon the beings within a world; those beings with the highest level of identity with the transcendental order structure are the physical bodies that carry out this enforcement in particular situations. The organizing logic of the world 'Los Angeles' finds its physical presence in the bodies and institutions that govern the world. Los Angeles, taken as a single world, is organized by the idea of LA as the land of sunshine; one who succeeds at achieving the capitalist promise of the city's booster myth is granted a maximum level of appearance within the city. However, within the many individual worlds contained by the city, the system of appearances changes based on geographic divisions such as economic and racial boundaries. The specific principles supported by the world's order structure may be modified due to historical change, but the "transcendental" truth of the system is maintained by those whose appearance is greatest within the world.

Badiou's system of ontology is able to account for fragmented urban space while also allowing for an idea such as the sunshine myth to organize the world 'Los Angeles' and the localized worlds found within. Noir texts focus on individuals trying to make sense of the material world that they inhabit, however the result is a disquieting understanding of the city's unknowability. These texts are preoccupied with the attempt to 
gain knowledge about individuals and the worlds they inhabit by penetrating their exteriors- the surface desires and motivations that shape the world—only to show that there is no substance underneath. The bored affluent youth, corrupt politicians and police, and seemingly benign visionaries that appear throughout noir texts modify the world around them, but escape implication because their level of appearance within the world grants them immunity from their actions. Furthermore, one does not have the same level of political and social capital as the groups above to be visible, for an individual's intensity of appearance within a world is measured in degrees, remaining relational to those with even the least appearance. Instead of being preoccupied with trying to uncover and understand why a world is the way that it is, noir texts focus on how individuals live within and move between various worlds, and how their being appears within the relational structure of those worlds. All cannot be rationally explained within a world, but one can understand how this strange type of world affects their ability to act within it.

Los Angeles noir literature and film explores the ontology of fragmented urban space by expressing how the emergence of the disconnected urban environment affects everyday life. From the futile attempts to enforce justice conducted by the hard-boiled detective to the middle-class crimes of desperation in early film noir, LA noir fiction exposes how individuals struggle to understand how they relate to the world around them when this world is completely unfamiliar compared to the type of urban spaces that were experienced up to this point. Chapter 1 traces the initial literary history of Los Angeles through an analysis of expressions of the Booster myth and the subsequent literary responses leading up to hard-boiled fiction and film noir. The originary myth that led millions to travel to Los Angeles offered impossible promises, and the failure to achieve 
these promises was felt by a majority of the city's middle and lower classes. This failure illustrates the affect that the fragmented space of Los Angeles had on the creators of these texts. Chapter 2 argues that the experience of this new urban space is marked by the failure of epistemological knowledge to provide any understanding of how these spaces operate within the larger world of Los Angeles. Through an analysis of the failure of vision to provide truth in Roman Polanski and Robert Towne's film Chinatown, this chapter demonstrates the experience of being caught in the transition between early and modern Los Angeles as witness to the very process of 'worlding' the city. Chapter 3 relies on Badiou's spatial ontology to further clarify how his notion of the transcendental order structure explains an individual's relationship to the city's social structures. Chester Himes's World War II-era novel If He Hollers Let Him Go provides a particularly stark depiction of the racial and economic impact of the worlds of Los Angeles on middle and lower class African- and Asian-Americans, two groups who struggled to maintain a minimal level of appearance within Los Angeles at the time. Finally, this thesis concludes by connecting the idea of an LA noir ontology to the contemporary urban environment of Los Angeles to show how the transitional anxiety expressed through noir literature and film transfers to the globalized world of the $21^{\text {st }}$ century. Contrary to the totalizing depiction of the world's order structure depicted in noir texts, Badiou theorizes a radical break that can occur within the world structure, located at the site that forms when that which is hidden by the world emerges from its margins. Through the development of a theory of noir ontology, this thesis suggests that LA noir texts express an underlying critique of post-industrial capitalist life that focuses on how physical 
bodies struggle to maintain their presence within an urban world that modulates appearance based on the particularity of space. 


\section{CHAPTER I}

\section{NOIR AS THE LOS ANGELES ANTI-MYTH}

From the earliest years of Los Angeles's development, the tension between mythic possibility and realistic disappointment has organized the city's cultural identity. While the city's promoters lauded it as a utopian paradise of sunshine, health and wealth, the absence of any real content to the utopian myth led to a generation of cultural commentators who established counter-representations of Los Angeles as a city of failed promises, where rhetoric never quite matches reality. For the writers and filmmakers critical towards the LA myth, the ideal city appeared much closer to the original Greek meaning of utopia - that is, a "not-place." The ever-shifting populace, the faux architecture found throughout the city, and the vacuity perceived in the upper class all contributed to the general perception that Los Angeles lacked what Raymond Chandler refers to as "the individual bony structure" that all cities should have (The Little Sister, 358). This chapter traces the line of texts that embodies the tension between Booster myth and lived experience. The promotional materials of late nineteenth century boosters and the literature of their early twentieth century responders first establishes this tension, but the hard-boiled novels of the twenties and thirties and their subsequent film adaptations through the forties and fifties produce a negative image of Los Angeles as an ideologically loaded sight of post-industrial capitalism. The archive of popular novels, 
pulp magazines, and melodramatic crime films set in LA is underwritten by the changes in everyday life that occur as a result of automobiles, subdivisions, consumer culture and a growingly disaffected managerial class. As a result, the noir body of work dissipates the mythic haze surrounding the Booster version of city, leaving nothing to cloud the reality of the order structure of post-industrial capitalist Los Angeles.

\section{The Literary and Cultural Identity of Los Angeles}

Because Los Angeles lacked the industrial manufacturing base of other major cities in the United States, the creation of the LA myth was necessary to the city's early growth. Charles Fletcher Lummis, a migrant from Ohio, took on the role of myth creator when he was hired to be the editor of the Los Angeles Times by Harrison Gray Otis in 1884. Lummis used the Times, along with several other journals that he edited, to promote the city to an eastern citizenry who were searching for any way to improve their fortunes. As the cultural arm of the city's Chamber of Commerce, Lummis represents "the key 'commodifier,' who understood that the 'epic story' could be deployed 'to lure tourists and settlers'" (McClung 26). In addition to the Midwestern agricultural workers who were susceptible to the promises of success, Los Angeles was also populated by middle-class migrants looking to escape the perceived social decline of the emerging $20^{\text {th }}$ century. Surrounding himself with similarly motivated writers and artists, Lummis and his group portrayed the city as "the promised land of a millenarian Anglo-Saxon racial odyssey ... a Mediteraneanized idyll of New England life [inserted] into the perfumed ruins of an innocent but inferior 'Spanish' culture" (Davis, $\operatorname{Co} Q 20$ ). This image, derived from the area's Spanish mission heritage and coupled with the availability of vast 
amounts of land, led thousands to invest in real estate, despite the lack of an economic base to sustain the population. Capital from speculators flooded the city, creating "the paradox of the first 'postindustrial' city in its preindustrial guise" (Davis $\operatorname{CoQ} 25$ ). Lummis used the inflated rhetoric of promise to sell the city to anyone in the Midwest who needed a new beginning. As a result, many were investing in a city which was incapable of living up to their expectations.

Lummis extended his project of promotion to the area's cultural scene through the journal Land of Sunshine. By including his own take on the region's history alongside others' regional work in art, archeology, poetry, fiction and photography, Lummis and his group were able to revise the history of Los Angeles to exploit its complicated precolonial and colonial past while simultaneously challenging San Francisco's claim as the cultural capitol of the western United States. While most literary contributors to the journal wrote short stories and poems set in a romanticized version of the Southwest Mission heritage, Lummis filled editorial columns with praises of the city's "intrinsic" wealth, beauty, and healing properties (Fine, ILA 42). Lummis sought to use the region's native history to posit his own version of Manifest Destiny with Los Angeles as the Promised Land. In one issue of Land of Sunshine, for example, Lummis separates the pre-colonial period of the region from its' actual history in order to remove any residual racial fears held by those from the East and Midwest, essentially white-washing the region's continuing multicultural heritage. "Southern California has a million square miles, a thousand years of legend, three hundred years of history," he proclaims (qtd. in Fine, $I L A 35$ ). For Lummis, non-European history is mere legend; only after the Spanish settled does proper history begin. This distinction further solidified the idea of Los 
Angeles as a European utopia at the cost of any factual representation of place and history.

While the literature produced by Lummis's group established the first wave of distinctly LA-focused writing, its purpose was far from accurately representing the experience of living and working in the city; instead, this initial literary movement played a large role in constructing the Los Angeles myth against which others would compare their own experiences. Lummis and his fellow boosters maintained the propagation of this myth until the 1920 s, when the motion picture industry emerged as the primary vehicle for Los Angeles promotion. As the dream version of Los Angeles came to dominate expectations, the contradiction between the lived experience of the lower and middle classes in Los Angeles and the representation of Los Angeles presented by the boosters led many of the city's resident writers to satirize the booster spirit. Writers such as Louis Adamic, Sinclair Lewis and H. L. Mencken responded to the idea of Los Angeles as a city of unlimited potential by characterizing it as an "overgrown Small town," where "an army of fly by night promoters, spiritual healers, medical quacks, and get-rich quick schemers" offered "panacea to an uprooted, unsettled, migrant population" (Fine, ILA 53). The simultaneous onset of the economic depression of the 1920 s and 1930s forced a situation where "jobless accountants and ruined stockbrokers stood in the same breadlines as truck drivers and steelworkers" (Davis, $\operatorname{CoQ} 36$ ). With the boosters no longer able to sustain their monopoly on representations of Los Angeles, the stability they implied was directly contradicted by the instability of a city built around myth and still emerging from the desert landscape. 
Such economic uncertainty could not stop the motion picture industry from using the available land to establish Los Angeles as the hub of the studio system, but many within the studio system were not immune from the disappointment felt towards the city's overblown depictions in media. With LA's growing film industry, established authorsincluding such names as Nathanael West, Aldous Huxley, and F. Scott Fitzgeraldflocked to the city to try scriptwriting. However, their film successes were minor compared to the novels that these émigrés wrote during their time in the city. David Fine argues that these writers faced a similar disappointment as those who migrated from the Midwest: "Their status as outsiders, their estrangement and sense of dislocation [was] expressed in moods ranging from fascination to revulsion and often a combination of the two." Fine continues, "In Los Angeles fiction the West Coast present is set, explicitly or implicitly, against a past brought from another place" (Introduction 2-3). Thus, many of these writers produced literature that reflects the void between past expectations and the present reality which they experienced as outsiders within the city. Of course, the manufactured setting of Los Angeles was bound to shock writers who knew only of the metropolises of the Eastern United States and Europe. Instead of finding the vertically connected modern cities of the $19^{\text {th }}$ century, Los Angeles lacked local tradition and matured haphazardly, forming a whole through the eventual merging of closely situated small towns. The city's architecture was cluttered with multiple competing styles and exhibited the randomness and impermanence of movie sets; this confusion leads Fine to comment that "the spectacle proved . . . irresistible to the novelists in their search for metaphors for cultural displacement and confusion, for the absence of tradition, order, and authority on the landscape" (Fine, ILA 19). Even though Los Angeles appeared as an 
utterly unique spectacle, it provided the setting for writers to explore the more

fundamental problems related to the emerging $20^{\text {th }}$ century.

In this initial phase of Los Angeles's cultural development, people's attitudes towards Los Angeles shifted from a romanticism towards its Spanish mission heritage and the idealism of its utopian possibilities to a skepticism brought about by writers who viewed the city with suspicion; all the while, the utopian undercurrent remained ever present as Los Angeles built its reputation as the city of the future. The dialectical tension between myth and reality was further complicated by the challenges that LA presented as a new form of emerging city, one that appeared altogether different from what had come before it. Los Angeles appeared as a mystery needing to be deciphered, and hard-boiled pulp fiction attempted just that.

\section{Hard-Boiled Fiction}

Hard-boiled fiction emerged during the 1930s as a response to the disappointment experienced by those living in Los Angeles during the period. By writing fiction that was "cynical in mood, fast in pace, unsentimental in tone, violent in action, and often narrated as vernacular, direct, first-person confessionals with minimal background or character development," novelists such as James M. Cain, Horace McCoy, and George Hallas replaced optimism towards Los Angeles with an idea of the city as the place where the American Dream of success had finally reached its demise (Fine, ILA 82). Hard-boiled fiction strips the psychological depth from characters in order to highlight how they exist as bodies moving through space, with their status within the city's social structure determined by their appearance within their environment. Instead of imagining Los 
Angeles as a place where one can fulfill the American Dream, hard-boiled fiction shows the dream to be empty; simple hard work and motivation does not explain the status of those who run amok within the city. Alternatively, Los Angeles is re-presented as a mystery, an unknowable city where upward mobility is mostly impossible despite one's best efforts. Powerful figures control the city by aligning with and upholding the dominant order structure that determines the world Los Angeles for all individuals contained within; occasionally one might stumble across a person's story of political or economic success, but these instances only work to shore up the LA myth. As an expression of the overwhelming social alienation, hard-boiled fiction contrasts the empty Los Angeles myth of the boosters with a fictional world controlled by political and economic elites in order to develop a conception of the city as a place overdetermined by its existing power structure, whether that be through politicians, bosses, or police.

In hard-boiled literature, the stories of crimes committed by the desperate middle classes express the individual desire to achieve easy success, while crimes of the idle rich underscore the anger felt towards those living off of Los Angeles's existing wealth. According to Fine, hard-boiled crime fiction links violent acts with "personal ambition, greed, and lust" (89). Furthermore, "the stories express the rage and frustration of the decade as well as the desperation to succeed, against the odds, in an America that was grinding people down" (90). Thus, in James M. Cain's novel Double Indemnity, the lustful excitement and financial gain from helping the wealthy Phyllis Nirdlinger murder her husband for his insurance money provides Walter Huff (renamed Walter Neff in Billy Wilder's film version) with motivation to risk his position as an insurance salesman; in fact, the skills that have enabled Huff's success to this point- his keen ability to 
interpret and manipulate statistics - provides him with the exact skills required to successfully commit such a crime. Alternatively, William Faulkner's noir short story "Golden Land" exposes the restlessness of a man who has traveled to California from the Midwest and has obtained the wealth and success that he desires; however, his marriage is failing, his idle children are involved in pornography and sexual scandals sensationalized by the press, and his mother is forced to bear witness to the consequences of her son's singular focus on obtaining wealth. Through these texts, hard-boiled fiction employs crime as a vehicle to explore the more abstract problems related to economy, sexuality, and ambition in the postindustrial world of Los Angeles.

As a result of hard-boiled fiction's focus on crime, the detective is most capable of interrogating the city's social and geographical composition. For hard-boiled detective authors, most famously Dashiell Hammett and Raymond Chandler, Los Angeles is a "metropolis of lies" where "artifice is everywhere," not just in the architecture (Babener 128). Crime in Los Angeles is presented as "a pervasive feature of the urban landscape, a network that crosses neighborhood, class, and racial division" (Fine, ILA 119). In attempting to penetrate this artifice in order to understand the underlying mechanisms of crime and politics, the detectives in hard-boiled fiction reveal little regarding the reality of the city's operations; at most, the hard-boiled protagonist highlights the existence of a division between the individual and established holders of wealth and power. As Mike Davis argues, "Chandler's [detective] Marlowe ... symbolizes the small businessman locked in struggle with gangsters, corrupt police and parasitic rich." The focus on economic self-interest creates "a constant tension between the 'productive' middle class and the 'unproductive' declasses or idle rich" ( $\operatorname{CoQ} 39-40)$. As a representative of the new 
post-industrial city, Los Angeles, with its empty history, labyrinthine urban structure and restless middle and upper classes, provides the perfect setting for the detective's search for a reality that exists once the LA myth is stripped away.

The significant feature that makes hard-boiled detective fiction a vehicle for interrogating the post-industrial city is its critique of the idea that crime in particular, and society in general, can be rationally understood and explained, which makes hard-boiled detective fiction notably different from traditional detective fiction. In the place of the crime scene where each element holds the answer to the criminal mystery is the decentered city where epistemological certainty proves impossible. Hard-boiled detectives negotiate a variety of spaces in order to gain knowledge, but along their journey, knowledge about the worlds that are navigated does not transfer into a total understanding of the city. As a result, little is ever accomplished after the hard-boiled detective's case concludes; the urban status quo returns even if the positions that were present at the onset of the crime are replaced with new faces.

The hard-boiled detective's inability to punish those who commit crimesincluding the completely legal actions of the wealthy that the detective considers the most pervasive form of crime - is reoccurring theme throughout LA noir detective fiction. Dashiell Hammett's detectives are set within a world filled with crime that they have no hope of changing, and in some instances no desire. Hammett critiques the modern system of social surveillance designed to prevent criminality that actuality protects those with the world-manipulating powers found at the root of crime. Justice is an empty concept in Hammett's fiction, as the world structure places no value on it. Raymond Chandler translates these themes into the concrete social environment of Los Angeles by 
exploring the many ways in which the city's power structure combines with the urban geography of Los Angeles to shape the way that the world of Los Angeles operates. With his car as the preferred method of investigation, Chandler's Marlowe traverses through the distinct neighborhoods that make up Los Angeles in order to reveal—or unwittingly hide - the corrupt actions of the wealthy. While Hammett did not set his fiction in Los Angeles outside of a single short story, his contributions to hard-boiled detective fiction undergird the genre's treatment of political and economic justice. To reflect the distinct locale of his personal experiences, Chandler places the hard-boiled detective within the specific world of Los Angeles, a world that he himself inhabits and whose world structure he is very much familiar with. The contributions of both Hammett and Chandler are significant within the body of LA noir texts.

\section{Dashiell Hammett and Urban Detection}

The former Pinkerton agent Dashiell Hammett's influence on noir representations of Los Angeles is grounded in his innovation of the "tough guy" detective found in cheap pulp magazines through the 1920s and 30s. Alongside Carroll John Daly, Hammett is credited with creating the hard-boiled private eye who must navigate through the political and economic regimes found in modern cities (Naremore 49). In Red Harvest, for example, Hammett describes a frontier outpost in the transition from town to fullyformed city, a time of "murderous labor struggles, White House scandals, and Prohibition-style gangsterism ... union busting and police violence" (Naremore 50). Hammett's Continental Op manipulates multiple gangs and corrupt police forces in the interest of his rich industrialist client, setting off a bloodbath that ends with the Op 
returning to his office in San Francisco to let "white-collar soldiers" reorganize the city, presumably at the dictate of his now-former client (Hammett 134). Thus, Red Harvest represents lawlessness as the result of "the direct imposition of law" instead of a result of "universal, ahistorical, or atavistic forces" (Heise 491). By destabilizing the moral authority of politicians, police, and even the professional detective himself, Hammett represents urban space as a place where "the true origins of crime--systematic police corruption, economic exploitation, state-sponsored violence-are not uncovered" (Heise 508). Moreover, the city's new "white-collared soldiers" will remain ignorant to the mystery of crime in the city, leaving the true mystery uncovered.

Hammett's Continental Op and his subsequent detective Sam Spade demonstrate how the classical detective's preoccupation with revealing the hidden motivations behind crime turns into a futile pursuit in hard-boiled fiction. In "From Modernity's Detection to Modernist Detectives," Christopher Raczkowski argues that the decline in the idea of the detective as a source of epistemological certainty can be traced to Dashiell Hammett's own experiences as a Pinkerton that formed his critique of vision as a source of knowledge. As an agent of the Pinkerton National Detective Agency prior to becoming a pulp writer, Hammett directly critiques the disembodied watchful eye used by the Pinkerton Agency as a symbol for their ability to reveal all that is hidden. Instead, Hammett draws a connection between surveillance and individual objectification by placing responsibility for the "crimes of humanity" on the "modern emergence of new social scientific projects diagnosing otherness and a disciplinary social surveillance" (Raczkowski 652). Individuals placed within a panoptic social system are reduced to objects while the justification for such surveillance - the seeing and understanding of 
crime-proves impossible when it is in fact the source of crime that controls the system of surveillance. Raczkowski notes that with the characters that Hammett's detectives encounter, "psychological depth, introspection, and interiority are not visible to the detective's sightlines or, therefore, the narrative's vision" (645). Thus, "Hammett's representational strategy, crystallized in The Maltese Falcon's titular statuette, is to repeatedly tell us that the object's surface conceals no hidden treasure-epistemological, psychological, or otherwise - for grasping subjectivity" (650). As individuals pursue objects with disregard to legal authority, concrete symbols of wealth become the only motivation for individuals in these texts; the possession of these objects provides a superficial sense of personal power for those characters. Moreover, Hammett's detectives are caught knowing their own powerlessness in the face of those who actually possess world-manipulating power.

Hammett's body of work challenges the traditional detective narratives of Arthur Conan Doyle and Agatha Christie, where the detective is an outside observer who can solve the crime if only he can find the clue in sight. In place of this figure, the detective is deeply embedded within urban social space, operating and oftentimes exploiting its order structure. At the same time, Hammett's fiction remains geographically isolated within the closed worlds that he creates. Raymond Chandler's detective fiction, in contrast, combines the author's own experiences living and working in Los Angeles with an acute attention to the city's geography, and the resulting texts reflect an environment where the landscape, and the power structures inscribed within, obscures the detective's sightlines. 


\section{Raymond Chandler's Los Angeles}

While Hammett's hard-boiled fiction establishes the representational strategy for political organization within detective fiction, Raymond Chandler's fiction embeds this world-view within the concrete urban space of Los Angeles. With the automobile serving as his tool for interrogating space, Chandler's detective Philip Marlowe must travel between the different neighborhoods that make up the city, negotiating the changing dynamics of each new world he enters. As Mike Davis notes, Chandler uses Marlowe to create the "street map of Los Angeles which Hollywood subsequently took as its guide," exposing "the class conflict of locales ... that made Los Angeles recognizably a city" ("Bunker Hill" 36). Through Marlowe's "ceaseless commutes between equally sinister extremes of wealth and immiseration," Chandler is able to represent the distinct worlds that make up the larger social system of Los Angeles, complete with its anemic history, class conflicts, and excess of wealth. Chandler's characters are embedded within this social world, and their actions are shaped by how they relate to the order structure within the Los Angeles of his texts.

Prior to his career as a writer, Chandler experienced the political and economic conflicts that would serve as inspiration for his representations of Los Angeles. Chandler worked in the oil industry, "a director of eight companies and a president of three, although I was simply a high-priced employee" (qtd. in Marling 193). While working for the South Basin Oil Company, Chandler witnessed the manipulation of stocks by oil company owners, culminating in the indictment of fifty-five wealthy Los Angeles citizens for defrauding the investors of Julian Petroleum. After a surprise acquittal, an employee of the County Efficiency Bureau discovered that the District Attorney that was 
prosecuting the case had taken bribes from the former owner of Julian Petroleum (Marling 189). Chandler prided himself for his ethical approach to business, even undermining his superiors when he thought it was necessary. Eventually, Chandler would be fired for his alcoholism; however, he chose to believe that it was his insubordination that was the cause. Never comfortable in California after living in England and moving through the Midwest, Chandler considered himself an outsider, a "secret knight . . battling the cheats" of society (Marling 200). Disenchanted with corporate Los Angeles, Chandler positioned himself against the wealth and excess of the city and refused to integrate into the economic structures that shape the city's social world.

Chandler's experiences in the oil industry contributed to his understanding of how the individualist ethos of capitalism was corrupted in a modern decentralized power structure that was in fact ruled by an elite few. According to Sean McCann, Chandler developed a "decentralist imagination," with a "distaste for centralized power, which was a standard perspective among Western industrialists, and an awareness of the ways in which that ideology was often compromised by its adherents" (145). Thus, Chandler's Los Angeles was "a city that aspired to centerlessness but that turned out in fact to be governed by concentrated power" (145). For this very reason, Chandler gravitated towards the pulp magazine industry that reflected a populist alternative to the centralization of economic power (145). When Chandler began writing detective fiction for Black Mask in 1933, he had already ended his career as an oil executive, and was passing through the worst of the Depression without work. As a result, Chandler was fascinated by the activities of LA's wealthy in his novels, from the Sternwoods of The Big 
Sleep to the Potters of The Long Goodbye. In both novels, the wealthy offspring of the business elites who are responsible for Los Angeles's development use their privilege to traverse the geographical boundaries of Los Angeles in hopes that the results of their actions remain isolated within each space. Chandler's critique of wealth reveals his underlying decentralist populism, however this populism is in no way optimistic.

In addition to the detective figure, Chandler's Los Angeles is populated by a wide cast of characters that reflect the city's actual social structure, including regular citizens and petty thugs, corrupt police and city managers, and the wealthy elite, which points to the complexity of decentralized urban space. Fredric Jameson has noted that for Chandler, these classes have "lost touch with each other because each is isolated in his own geographical compartment," yet geographical isolation does not necessarily entail complete disconnection (69). Even though the space of Los Angeles is decentralized, the characters that populate that space form a "situated relational network" (Badiou 118) that allows for one to make sense of city's order structure. As Badiou argues in Logics of Worlds, to appear fully as an object in the world one must align with the elements of the world that belong to its order structure. In Chandler's noir version of Los Angeles, for instance, private property, the amassing of wealth, and generational legacy constitute just part of the world's relational network. As the sunshine myth proclaims, Los Angeles is a place where anyone can succeed as long as they have the ingenuity—or amoral drive-to pursue such a task. Furthermore, the idea of Los Angeles privileges those who have achieved its goals, thus those who possess wealth appear fully in the world even if they themselves did nothing to earn it, a fact which can explain the young idle rich that appear throughout noir texts. 
Instead, the effect of Los Angeles's geographical fragmentation is that one's appearance is not consistent as one moves between worlds. Because a world is 'worlded' when the local site's dominant ideology is solidified as a transcendental truth for that world, objects, including bodies, are organized based on their level of identity with that which is raised to the status of truth. However, the world of Los Angeles as a whole does not have the only determining order structure. As one moves within the individual spaces contained within the larger world, the order structure changes to match the relations of that world. Thus, the wealthy world of West Hollywood orders the appearances of individuals differently than the world of decaying Bunker Hill, or the world of City Hall. A locale populated by struggling migrants trying to stay afloat during the Depression years, for instance, is structured by the relation between those individuals who have experienced the vacuity behind the sunshine myth. Thus, the order structure of this localized world orders the intensity of appearance based on a set of principles that is different than the spaces ordered by the apparent truth of this myth.

By using the space of Los Angeles to show the social effects of increasing centralization, Chandler reveals how the individual worlds within the city relate to the world of the city as a whole and traces how wealthy criminals move between worlds, often without punishment, because their appearance within the world absolves them from any legal responsibility. The relationship between the organization of worlds and the actions of those within various worlds is best expressed in Chandler's first novel, The Big Sleep. In The Big Sleep, the detective Philip Marlowe travels from the wealthy heights of the Sternwood mansion, to Hollywood Boulevard and the quickly decaying neighborhood of Bunker Hill. From the first chapter in which Marlowe enters the Sternwood mansion, 
Chandler contrasts the world of wealthy Los Angeles society with what would be familiar to those who work and labor outside of that world. Marlowe is immediately captured by the objects of wealth that appear within the house: the entrance doors that "would have let in a troop of Indian elephants," the "large hard chairs with rounded red plush seats" that "didn't look as if anybody had ever sat in them," and the "white garage, in front of which a slim dark young chauffeur in shiny black leggings was dusting a maroon Packard convertible" (BS 3-4). Marlowe is presented a world of full appearance, down to his brief meeting with the younger of Sternwood's two daughters, Carmen, with "slate-gray" eyes that had "almost no expression" (BS 5). Even the General's greenhouse, filled with natural objects, presents an artificial world where "the air was thick, wet steamy and larding with the cloying smell of tropical orchids" and "plants filled the place, a forest of them, with nasty meaty leaves and stalks like the newly washed fingers of dead men" (BS 5). From the very onset of the novel, Chandler disorientates the reader by assaulting them with perceptions of the objects that constitute the world of Sternwood's mansion. Marlowe finds himself in a strange world that few have access to, a mansion sitting above the rest of Los Angeles, closed off from the rest of its surroundings.

But while the Sternwood mansion seems to be a completely separate space without any connection to the surrounding world, Chandler positions the house in such a way as to make clear the family's relationship to the rest of the world of Los Angeles. From high in the hills of West Hollywood, the Sternwood mansion overlooks "some old wooded derricks of the oilfield from which the Sternwoods had made their money. Most of the field was public park now, cleaned up and donated to the city by General Sternwood. But a little of it was still producing in groups of wells pumping five or six 
barrels a day" ( $B S 21)$. However, the family remains completely separated from these surroundings: "The Sternwoods, having moved up the hill, could no longer smell the stale sump water or the oil, but they could still look out of their front windows and see what had made them rich. If they wanted to. I didn't suppose they would want to" (BS 21). By highlighting the gap between General Sternwood and the source of his wealth, which is well out of his hands at this point, Chandler separates the character of Sternwood as presented on the page from Sternwood as he exists within the context of Los Angeles's development. In fact, the aging General himself appears sympathetic in comparison to his daughters, neither of whom he admits "have any more moral sense than a cat" (BS 13). Physically, he is wheel-chair bound, "an old man two-thirds dead" with the pulse "in his lean gray throat" visibly throbbing. However, the symbolic importance that a figure such as Sternwood holds within the space of Los Angeles reveals his vitality: the General has bled the city's most abundant natural resource dry, shut his self off from the world that he created, and allowed for his daughters to travel "their separate and slightly divergent roads to perdition" without consequence (BS 13).

General Sternwood's symbolic position within Chandler's Los Angeles reveals the centralization of power that marks the city's development through the first half of the twentieth century. While Sternwood is absent from the day to day activities that occur within the city, his reach extends through the network of individuals that he is able purchase, no example being as clear as Marlowe himself who the General requires as his interpreter of decentralized urban space. Chandler offers little information as far as Sternwood's motivations, but the General admits that his sense of morality is as lacking as those of his children. Nonetheless, he exerts an influence over the events of the novel 
because his success as an early industrialist has placed him in the position to where he represents the organizational structure of the surrounding world, even though his body is isolated within his mansion.

The General's status as one of the industrialists who are responsible for the city's present wealth positions him in alignment with Los Angeles's order structure. Because the mythic identity of Los Angeles shaped the political and economic reality of the city's early history, the principles of unchecked capitalism and the absolute achievement of upward mobility —-the total actualization of the claims of boosterism—form the city's order structure. Sternwood represents this complete fulfillment of a dream, and thus maintains a maximum level of appearance within Los Angeles. Sean McCann refers to this order structure as the "fiscal system" that lies at the heart of Chandler's novel (167). The Sternwood wealth is at the center of this fiscal system as "wealth that ... depends on a nearly exhausted source of primitive accumulation" (167). No matter if one is obtaining wealth and success through legal or illegal means, one's participation in the system of wealth accumulation determines their level of appearance. Thus, the police in the novel refuse to worry about the disappearance of Rusty Regan, an ex-bootlegger and Vivian Sternwood's estranged husband, saying that it is only temporary because he must "get back in the fiscal system" in order to sate "the same old appetites" that brought Regan wealth and status. In other words, Regan's status within this world does not matter to the police because he is only a concern when he appears within a world whose ordering the police are charged to enforce. The fact that Regan fled town with the wife of the gangster Eddie Mars makes his appearance "earthy" and "vulgar"- the exact opposite 
of the wealth and class needed for one to have a high level of appearance within the world of Los Angeles.

The end result of Sternwood's position within the world of Los Angeles is that his two daughters, Vivian and Carmen, are able to use the world's order structure to their advantage, using the city to chase whichever desires capture the moment. Vivian, the older of the two children, is caught up in Eddie Mars' gambling racket, however the large amounts of money that she wins and the debt that she accumulates cyclically is allowed by Mars because they sustain each other within the fiscal system. Carmen has less luck than her sister, due in large part to the worlds in which she is active. The initial mystery of the novel centers around an anonymous blackmail note written to extort money from the General by exposing Carmen's gambling debts and involvement in a pornography ring. While Vivian is calculated in choosing which worlds she appears in, Carmen finds herself in a much more anarchic world made of pornographers and gangsters who act more out of self-interest than out of a desire to participate in the city's fiscal system. Thus, when Carmen is exposed as the one who murdered Regan, dumping his body in the nearby oil slump, she is institutionalized where "they can handle her type, where they will keep guns and knives and fancy drinks away from her," that is, keep her away from the worlds where her appearance - and physical being — can be threatened (BS 228).

Chandler offers no reason to believe that the world's order structure will change, and for that reason his fiction upholds the concretization of the Los Angeles social structure. Peter Rabinowitz argues that over the course of The Big Sleep Marlowe descends "from moderately optimistic knighthood to a despairing recognition of his own impotence" as the closest figure to a villain other than Carmen, Eddie Mars, goes 
unpunished and he realizes that nothing can be done about the world that has allowed the events of the novel to occur (125). Marlowe is capable of performing good acts, but "this is a far cry from the administration of justice, which Marlowe comes to realize is not longer possible for an individual in our urban society" (Rabinowitz 125). All that he can do is remove himself from the fiscal system, which he does by refusing the large sum of money offered to him by Vivian in exchange for not incarcerating her sister. Marlowe returns downtown, where he can continue to make twenty-five dollars a day plus expenses working as a private eye, a detached observer moving through space.

Throughout The Big Sleep, Chandler uses the Sternwood family to expose how the Los Angeles myth is turned into a corrupt reality where evil is "too well organized and too well protected by 'legitimate' institutions" and thus "cannot be uprooted by logic alone" (Rabinowitz 130). While the General embodies the city's booster spirit, his daughters become its logical extension-they use their appearance within the worlds of Los Angeles to fulfill their base desires. Chandler attempts to make sense of the decentralized urban geography of Los Angeles that also includes a centralization of political and economic power, uncovering a strange and unknowable world. Chandler's investigations into this strange world highlight the dialectic between sunshine and noir, where the pursuit of an ideal future is met with a very different reality.

Los Angeles's early literary and cultural identity involves a tension between a dream of the future and the reality of the present. From the early days of Lummis and his fellow boosters, through the hard-boiled detective fiction of Chandler, cultural producers have attempted to reconcile this tension by revealing the decentralized world of Los Angeles and interrogating the subjective experiences that occur within its space. 
However, since this decentered city is unknowable in the way that scientific rationality understands, all one can expect to know is how the individual relates to this new kind of world that privileges various persons based on the intensity of their appearance. While Marlowe negotiates the spaces of crime, privilege, wealth and corruption, his presence in Los Angeles remains detached; at the end of The Big Sleep, he is able to return to his own neutral space, unchanged other than having his cynicism validated further. However, as many other noir texts have shown, the detective cannot always return to their private space unchanged. For, if a world's ontological structure is always relational, then one cannot ignore the ordering structures that affect an individual's level of appearance. 


\section{CHAPTER 2}

\section{CHINATOWN AND THE WORLDING OF LA}

The new experience of fragmented urban space contrasts with how scientific observers had conceived of the geography of the city before mid- $20^{\text {th }}$ century. Like the disembodied eye that symbolizes the Pinkerton Agency's ability to see any crime, the detached detective appears to be the lone figure capable of pulling together disparate facts found throughout the city to explain its operations. Ed Dimendberg observes that the Los Angeles private eye is a "kind of mobile perceptual center that links concrete experience with a social and political structure of growing complexity" and that noir texts

"generat[e] spatial knowledge, a cultural strategy to bridge the gap between everyday life and institutions" (171). However, epistemological investigation does not result in the expected total knowledge base because the divide between institutional knowledge and lived experience forms what radical urban theorists have called the "epistemological gap in our knowledge of the city" (Howell 364). Noir representations of Los Angeles establish that having the facts about a set of actions does not mean that one understands the world in which those actions take place. Concepts such as legal responsibility, political ethics, and the enforcement of justice only appear within the world's order structure when they are applied to those who already have a diminished level of appearance within the world. 
These themes are expanded upon in Robert Towne and Roman Polanski's 1974 film Chinatown, where the detective's pursuit of a solution to the mystery is secondary to the detective's uncovering of a strange, seemingly anarchic world. The film's detective, Jake Gittes, assumes that he is attempting to solve a simple adultery case, albeit a highprofile one. However, Gittes's quest soon turns into a personal struggle to accept that knowledge is inadequate in this new type of world; knowing the objective truth behind this urban mystery does not mean that the story's antagonist can be brought to justice. As a result, Gittes struggles to accept the order of a world that is altogether different than the one he believed in as a former police detective. Chinatown represents a version of Los Angeles where the world's order structure is completely determined by the capitalist drive expressed by the sunshine myth; Gittes's knowledge of events cannot force justice in a world where political operations follow no logic. Instead, Gittes is forced to ask himself about the very nature of the world in which he exists. When the film documents the erasure of Southern California's natural spaces in order to facilitate Los Angeles's growth, it also documents the very 'worlding' of LA-the process by which the idea of Los Angeles is cemented as the world's organizing principle. Through its symbolic representation of the city's booster spirit, Chinatown demonstrates the stabilization of the world through the entrenchment of its order structure, establishing the dominant ordering process into the future of modern Los Angeles.

\section{Towne and Polanski's Los Angeles}

As "an acknowledgment that I lived with things I loved but could no longer see," Robert Towne's script for Chinatown is steeped in the memories of his childhood, an 
idealized memory where one could "look down the tracks to the mountains and sky and the pastels of lavender, salmon and blue of old tile-topped motels long since blown to rubble" ("Chinatown-A Screenwriter's Eulogy," 64). Noticing that this world was quickly disappearing due to modern development, Towne set out to preserve the final evidence of this early Los Angeles on celluloid, capturing what little past had not yet disappeared due to "time, smog and development" (68). Towne's memory, however, is formed just as much by Chandler's depictions of the city as his own recollections. Set during a time period when the city was first struggling to provide resources such as water to its inhabitants, Chinatown depicts the city's original planners as strategic manipulators of public attitudes towards development, all for the sake of realizing the promise of unlimited growth supported the booster myth of Los Angeles. The film's antagonist, Noah Cross, embodies this booster spirit as he is willing to do any action, no matter how wrong, to carve the city out of the desert landscape and ensure the existence of the city well into the future. In fact, Towne's script condenses thirty-plus years of real world political debate surrounding the construction of the city's aqueduct, and places it within the depression-era period used by Chandler's fiction. Through the resulting film, Towne offers his own causal explanation for LA's development from a city surrounded by coastal waters, desert fauna, and towering mountains to a metropolis of asphalt, steel and smog.

Towne's script captures the process of the city developing from the natural world into a sprawling set of housing developments reaching far into the surrounding valley. In The History of Forgetting, Norman Klein offers a definition of a site-specific social imaginary that captures the process of urban erasure also captured in Chinatown. 
Departing from the Lacanian or Hegelian sense of the social imaginary, Klein focuses on the built environment, "particularly sites that were destroyed or altered" (9). In many ways, this conception of the social imaginary documents erasure and maps the sites that "escape any category, and can be found only by the trail it leaves, by its evacuation" (10). The slums, according to Klein, are just one example of this site-specific social imaginary, where attitudes towards the slums are defined by the "fears of upscale professionals afraid to enter a seemingly dangerous street" because it marks the absence of white order (11). Noir representations of Los Angeles are constructed upon a similar feeling of the loss of an idealized space, for as already noted, noir literature and film responds to the absence of the site promised by the Los Angeles myth. The loss of the more natural Los Angeles that Towne recalls when reflecting upon his inspiration for the script mirrors the romantic idea of Los Angeles as a natural paradise - the arroyo landscape punctuated by the few human markings of electric wires, yellow street lamps, and tile-topped motels ("Chinatown-A Screenwriter's Eulogy,"64). To express the processes of erasure, Towne represents the outskirts of Los Angeles as places that are struggling to resist development, and must inevitably fail. In contrast, the urban spaces of the film are marked by a tension between nature and development, from the manufactured yard of the Mulwray house to the courtroom overcome by herds of sheep. Individual characters are marked by this tension as well, most notably the Mulwray (grand)daughter whose very life stems from an incestuous violation of nature.

Moreover, Towne views this erasure of nature as not only a crime, but a sin. By moralizing the actions of the city's founders, Towne connects their actions with a 
fundamental evil instead of looking at the purely political and economic motivations behind their actions. He comments:

Whatever the crime in Chinatown, greed wasn't represented by moneyland and water, respectively, did that. But the central crime of Chinatown - the wanton destruction of the past - wasn't a crime at all. . . The truly murderous act in the movie was laying waste to land and to fragile communities as though they were an incidental part of Noah Cross's grand vision. . . When a crime can no longer contain or content itself with the past and insists on visiting the future, it's no longer a crime-it becomes a sin, very difficult to punish and even more difficult to dramatize ("Chinatown-A Screenwriter's Eulogy,"66).

By referring to the crimes perpetrated in the film by Cross as sins, Towne indicts the very processes used in the building the Los Angeles that we know of today. Additionally, in minimizing the crimes of the film in order to highlight a perceived fundamental sinfulness, Towne moves from the empirical process of solving a single crime to the ontological process of uncovering the existence of an urban world that appears to the writer as constructed out of sinful acts.

Of course, one cannot ignore the influence that director Roman Polanski had on the final version of Chinatown's script. The problems that Polanski and producer Robert Evans had with Towne's first script have been well documented, ${ }^{3}$ however Polanski's experiences in Los Angeles modifies Towne's vision of the city. Whereas Towne's vision of Los Angeles mourned the loss of a semi-fictitious idyllic past, Polanski's experiences within the city were much more tragic. Prior to filming Chinatown, Polanski's wife, Sharon Tate, was murdered in their rented Los Angeles home by followers of Charles Manson. Polanski's wife was eight and a half months pregnant at the time of her murder. According to Benedetto, the director modified the script to express the theme of "the

\footnotetext{
${ }^{3}$ To read the full explanation of Towne and Polanski's debate over the film's depiction of Los Angeles, see Benedetto.
} 
omnipresent heart of darkness and man's powerlessness in the face of it" within a distinctly urban setting (49). Even though Towne raises the legal crimes of the film to the level of ethical violations, he does not go as far as Polanski in characterizing crime as a fundamental part of urban existence. For Towne, Los Angeles is a city that could have been saved, but for Polanski, LA is a place where darkness is inextricably woven into the very fabric of the world. Thus, Polanski shifts the focus of the film from a detective who is powerless to bring about justice (as was Marlowe in The Big Sleep) to an individual who is struggling to understand how the world operates and how one can exist within such a world.

\section{Photographing Crime and the Failure of the Visual}

At the beginning of the film, Gittes's detective work is limited to simple adultery cases where his investigative process only requires him to find an individual, document their transgressions, and then provide the evidence to his client. This process involves a simple quest for objective knowledge because once a fact is documented, the truth is exposed. In these cases, the detective is detached from the world in which he investigates-one is simply an observer without any emotional attachment to a case. In fact, Gittes's choice to specialize in this type of case stems from his own failures as a policeman in Chinatown, where he was involved in one that ended with the murder of a woman he loved. The cases that form Gittes's focus aligns him more with the Pinkerton method of detection described above; the eye, through the lens of a camera, can see and document any crime. Gittes's methodology at the beginning of the film points to the twentieth century's increasing reliance on social surveillance, where "the reification of 
individual knowledge and rationality in detective fiction paralleled a more subtle support for order and the disciplinary power of a police state" (Farish 106). Urban geographer Matthew Farish notes that photography "was an ideal tool for detectives in their quest for knowledge. Appropriated by criminology and fiction as a 'guarantor of identity and as a means of establishing guilt or innocence,' photographs could locate individual traces within the anonymity and confusion of urban crowds" (106-107). However, the technique of visual documentation is inadequate for forming a total understanding of fragmented urban space. Contrary to the truth guaranteed by photography, "the twentieth century's crisis of visuality —in terms of both vision and visibility—led literary modernists to interrogate the relationship of viewing subject to object viewed and to reconsider the epistemological limits of narrative constructions of the visible" (Raczkowski 630). In the noir world of Los Angeles, the knowledge that the eye captures becomes an object whose truth is not guaranteed. For this reason, Gittes is forced to learn new methods for interpreting urban space.

Through Gittes's initial successes and subsequent failures at documenting apparent adultery, Chinatown further exposes how the visual does not always guarantee epistemological knowledge. At first, photographs are capable of establishing truth. The film begins with Gittes showing several photographs to a client, Curly. Curly had hired Gittes to follow his wife who he suspected of adultery, a suspicion that was easily confirmed. In this case, Gittes is able to visually capture the truth, but the truth proves too much for Curly. Overcome with grief, the shattered husband attempts to consume the venetian blinds in Gittes's office, symbolizing that "has had a little too much reality and wants to recover his condition of less painful blind-ness" (Gilmore 124). For Curly, the 
visual succeeded in providing epistemological certainty even though the truth proved painful. In contrast, photography fails to provide epistemological certainty when Gittes is hired by a woman posing as Evelyn Mulwray. Thinking that he is working on just another adultery case, Gittes tracks Hollis Mulwray, the director of the city's Department of Water and Power, and observes the suspected adulterer as he testifies at a public hearing in City Hall, questions an anonymous child in a dried up riverbed, and spends an evening observing the city's ocean coastline. Eventually, Gittes captures the evidence he needs by photographing Mulwray with a young woman; the photograph ends up on the front page of the city's newspaper, and as a result, partially discredits Mulwray in the eyes of the public. However, the apparent truth that Gittes's photographs provide proves false. The woman who hired Gittes was an actor, and the relationship between Mulwray and his supposed lover is non-romantic. Richard Gilmore argues that this oversight on the part of Gittes is due to an optical scotoma, which is the blind spot occurring in eyesight that the mind automatically fills in: "He is constantly being surprised by things he failed to see or, rather, things for which he saw the signs but failed to read them properly because of his own preconceived ideas about what the signs must mean" (125). The blind spot in Gittes's vision exposes the epistemological gap in knowledge that the optical cannot account for. Gittes's methodology as a private eye relies on his ability to see and document truth; however, behind the appearance of truth, a world exists that Gittes is unprepared to investigate.

\section{Understanding Urban Space}


When the camera fails to provide the answers to Gittes's pursuit of certainty, his investigation changes from epistemological to ontological in nature, requiring a shift in his methodology as a private eye as a consequence. When the real Evelyn Mulwray confronts Gittes after news of her husband's apparent affair is leaked to the press, his investigation uncovers a conspiracy to control the city's water supply. However, each discovery only destabilizes Gittes's conception of the world in which he inhabits-instead of uncovering the truth to the mystery, Gittes finds that the urban landscape obscures the actual events that are occurring within the city. As a result, Gittes must travel through the world of Los Angeles, his car replacing the camera as his method of interpretation. He pieces together fragments of truth in hopes of solving the case; such hope proves futile, however, because Gittes finds the world to be qualitatively different than what he had believed. Thus, the detective's case becomes an interrogation of the nature of the world in which Gittes finds himself.

Cities constructed around the automobile are expansive, and the automobile allows individuals to experience space in new ways. The result of this development, according to Dimendberg, is that the car "initiates novel perceptual and behavioral practices - new experiences of time, speed and distance--no less than new features of the everyday landscape" (169). Furthermore, Enda Duffy argues that the resulting experience of speed "revolutionized people's sense of space and territory" (par. 5). Accompanying the experience of speed was a new kind of politics, "a politics of access" where "the rich were granted greater speeds earlier" and therefore could take advantage of the expansion of space (par. 22). Throughout Chinatown, automobiles play important roles in detection: Gittes tracks Hollis Mulwray's movement by placing a timepiece 
under his tires, drives through the surrounding region searching for clues, and uses Curly's truck to try to send Evelyn and her daughter away from Cross's reach. Most significantly, uncovering the film's mystery would be impossible if Gittes could not travel quickly throughout Los Angeles and the surrounding region to piece together fragments of truth.

Noah Cross's successful attempt at manufacturing a water crisis in order to develop the city's system of supply rests on his ability to obscure his actions by spreading them out throughout space. Cross has water dumped through various flood channels at night in order to make the city's water supply seem scarcer than it actually is. Observed individually, the dumping seems insignificant, easily dismissed by some technical explanation from the water department. However, when Gittes notes that water is being dumped through numerous channels, the location changing every night, the larger mystery becomes clearer. Towne highlights the experience of expanding space in his script. Surveying his scene descriptions of when Gittes is uncovering the mystery of the flood channels, one notes the necessity of the automobile in solving the mystery: "Riverbed—Dusk," "Gittes in Car_Nightfall," "Gittes in Car-Moving," "Farther Up_ Moving," "Still Farther-Night" (Towne, Chinatown 50-51). As the scenes rapidly progress, Gittes remains isolated in his vehicle, observing individual elements as he passes by each site. Every shot takes Gittes further up Hollywood Hills to the Oak Pass Reservoir while he pieces together information to try to understand the larger state of affairs.

The enormity of Cross's conspiracy would be impossible for Gittes to comprehend if he could not visit each of the worlds that Cross uses to complete his task. Each space 
that Gittes visits contains a distorted view of Cross as different elements of his person appear in greater or lesser intensities based on the world that he is in. Within his missionstyle hacienda isolated on its own coastal island, Cross is a retired city planner and benevolent patriarch, using the land to manufacture the pastoral ideal of pre-developed Los Angeles. To the residents of the Mar Vista Rest Home, Cross and his co-conspirators at the Albacore Club are kind philanthropists even though they use the identities of deceased residents to buy up the city's surrounding farm land. When downtown, Cross exists outside of the law because he helped to build the very city. On the surface, Cross's status within each world appears normal, but by traveling to each world and piecing together the larger picture, Gittes is able to observe different elements of Cross's identity to understand his role in the city's water conspiracy.

Within the ontological structure of Los Angeles, Cross functions as what Badiou refers to as "the envelope," a level of appearance that stabilizes the order structure of a world. In order for an individual to be granted a certain level of appearance by the order structure, that individual must be recognized by another being whose appearance is already guaranteed in that world: "The thinkability of a being . . . follows from two things: (at least) one other being, whose being is guaranteed, and (at least) one operation which justifies thought in passing from this other being to the one whose identity needs to be established" (LoW 113). Once this is accomplished, the previously unrecognized individual is situated within the system of appearances that orders individuals based on their level of identity with the order structure; when the order structure is based around capitalist growth, for example, the resulting organization maximizes the appearances of those who follow this ideology most closely. As a result, a set of individuals-or a single 
individual—exists that has the maximum level of appearance. Badiou argues that "the existence of a maximum is a worldly principle of stability... The maximum of appearance distributes, unto the beings indexed to it, the calm and equitable certainty of their worldliness" (LoW 139). Thus, this set is the physical manifestation of the organizing principle, made up of those individuals who guarantee the stability of all beings by ensuring recognition within the world even if a being is granted the absolute minimal level of appearance, that is, recognized for their physical presence only.

Cross's status as the envelope holds true for Los Angeles as a whole as he provides stability in the world, and therefore his maximum level of appearance extends to the many smaller worlds that it contains. Within the order structures of worlds represented in Chinatown, no individual can have a higher level of appearance than the individuals who imagined the very mythos on which the city is constructed.

Furthermore, Cross's actions are not illegal, or even morally wrong, because the principle of capitalist development forms the transcendental truth on which the entire world is organized. However, this state of the world is lost on Gittes because he does not understand his existence within this particular world. Gittes's methodology has brought him the knowledge that he needs to bring Cross to justice, but these facts are useless in a world controlled by Cross. Unable to use his knowledge to change the state of the world, Gittes inhabits a space that he cannot understand. Naremore notes, "The ordinary institutions having failed, he remains locked in a world of irrational greed and sickness, and his consciousness of that world has left him so numb he can barely move" (209). However, Naremore's claims of institutional failure and irrational greed ignore the nature of the world that Gittes inhabits. As the guarantor of world stability, Cross structures the 
operation of the world so that his actions align with its order structure. As a private eye, Gittes believes that his relation to the world around him is understandable; he works to uncover facts, rationally construct them into a narrative, and believes that this is sufficient to change the state of affairs within the world around him. Instead, Gittes finds himself in a world where truth and reason do not determine one's role within the world therefore Gittes is in direct conflict with the world of Los Angeles represented in

\section{Chinatown.}

\section{Organization of a Legacy}

In addition to the principle of capitalist accumulation, legacy forms a significant part of the world's order structure. As the idea of Los Angeles is one of a place waiting to be shaped, success is measured by one's ability to control the city's development into the future. Cross's control of the city's political economy supports the order structure of unchecked capitalism that is obscured by the booster myth, but his violations of sexual economy constructs a world that will persist into the future, inscribing his being into the very landscape of Los Angeles. Gittes's conception of the world around him unravels when he uncovers the film's darkest secret - that Noah Cross was involved in an incestuous relationship with his daughter Evelyn which produced his (grand)daughter Katherine, the mysterious young woman that Gittes photographed earlier in the film. Cross expresses his world-shaping vision when Gittes asks Cross, "What can you buy that you can't already afford?" He simply replies, "The future, Mr. Gittes - the future." Through Cross, Towne and Polanski clarify that those who shaped modern Los Angeles were not short-sighted business opportunists, but full adherents to the booster mythos 
who looked forward in time towards a future that they would surely not be around to witness. Furthermore, they understood that if they were successful in creating the sprawling metropolis of the future, their means would be justified. Cross himself admits this fact when he tells Gittes, "Politicians, ugly buildings and whores all get respectable if they last long enough." Los Angeles's future development will hide all the crimes committed by Cross in the present.

The idea of manipulating progress is implicit in an order structure constructed around capitalist accumulation because owning the future itself is the most valuable possession in the world of Chinatown. Even though he holds no elected office, Cross is able to control the world around him with the expressed purpose of developing Los Angeles into a sprawling metropolis; by buying up land north of Los Angeles with the goal of "bringing LA to the water," Cross intends to cement his legacy within the urban structure of Los Angeles. Vernon Shetley argues, "Both daughters and water represent the possibility of fertility, of the growth and renewal of life; and so both are significantly linked to the 'future.' Each is a means of projecting oneself into the future, either through bloodlines, or the creation of wealth, for what is capital but wealth that has outlived its creation, even creator?" (1098). Alternatively, Stephen N. doCarmo warns against conflating crimes of political and sexual economy by noting that "the two are too different to be equated, and Cross's name itself indicates we are dealing with an intersection of disparate drives, not just various manifestations of a single one" (649). In separating these two drives, doCarmo reduces the film's sexual transgressions to base human desires. As a result, doCarmo ignores the significance of the actual act of incest; if Cross's actions could be explained by his sexual drive, then there would be no reason 
for him to choose his daughter in particular. Furthermore, Cross's obsession with possessing his offspring shows how deep his drive for controlling the future rests. Evelyn may have been "lost to [him] long ago," but he must take possession of his (grand)daughter, a synecdoche for the Los Angeles of the future.

Thus, Chinatown identifies the actions of Noah Cross, both personal and political, with an order structure of unchecked capitalism where the future is the commodity that is most valuable - no relation between individuals is more important than this principle. Shetley argues that "Noah Cross's crimes against the public, then, go beyond a simple scheme for self-enrichment; the appropriation of public property for private ends becomes, like incest, a crime that violates the entire social contract and undermines the very possibility of organized social life" (1100). While numerous critics beyond Shetley have noted that the incest theme in Chinatown shows the extent to which Cross will violate laws to achieve his legacy, a consideration of Cross's role as the envelope for the world of Los Angeles shows that his actions do not undermine the possibility of organized social life, but represent a reorganization of social life along the lines of the order structure established through the city's booster myth and early history. For the film's symbolic booster, water theft and incest enables the city to exist in the first place: first, by ensuring the structural development of the urban world, and secondly, by possessing and protecting the future so that his control can persist after he is dead.

\section{Chinatown as the City's Absent Center}

The conflict between Gittes and the order structure that Cross stabilizes comes to a head in Chinatown, the city's ultimate undecipherable space. Until the final scene in the 
film, little is known about this world other than that Gittes and Escobar worked there early in their careers, and Gittes had been involved with a woman who was murdered in the district because he violated the District Attorney's rule to do "as little as possible." The mystery behind Chinatown expresses a deeper fact about the noir world of Los Angeles - located at the geographic center of the city, Chinatown's unknowability reflects the absence of the point which guarantees epistemological certainty. Instead, Gittes finds himself directly confronted with the world structure that Cross enforces. When Gittes enters Chinatown, he has already had his knowledge of Hollis's murder confirmed by Cross. Still believing that this knowledge is sufficient for saving Evelyn and making Cross pay for his crimes he appeals for Escobar to hear his case, but knowledge is insufficient in this world. Cross controls the police, just as he controls the water, his children, and the world of Los Angeles. Vision fails at providing an understanding of the city and its order structure when Evelyn is shot through the eye. Furthermore, in perhaps the film's most haunting moment, Cross uses his hand to cover Katherine's eyes to the horror, denying her sight of the painful fact that the future - and her future-is the result of his present actions.

Gittes's experiences in Chinatown seem to encourage a worldview where any action for the sake of a principle such as justice is discouraged. DoCarmo argues that the film's conclusion represents the "postmodernist quietism" that disallows inquiry, knowledge, and action. "[W]hen Chinatown looks out on an indeterminate reality in which 'you can't always tell what's going on,' it does not see opportunities for society's disenfranchised to make their mark on history," doCarmo notes. "It rather sees opportunities for the dominant and corrupt to further expand their power, an eventuality 
only accelerated by any struggle against it" (651-652). The imperative to do "as little as possible" confirms this warning against any action that modifies the world one inhabits. When Gittes's knowledge of Noah Cross's crimes is insufficient for him to affect change within the world, he returns to his matrimonial work; in the film's sequel The Two Jakes, Gittes is a middle-aged shell of his self, cynical towards the organization of the world around him.

The version of noir Los Angeles presented in the film shows a world whose order structure is stabilizing around the principles that underwrite the sunshine myth of the city's boosters. Despite his best efforts, Gittes is ineffective when it comes to interrupting the events of the film. If anything, his actions only worsen the cost. When optical methods of investigation prove inadequate, Gittes must adapt to fragmented space and adjust as he moves between worlds. However, he remains committed to the truth of political justice even though this value does not factor into Los Angeles's overarching order structure. As Cross guarantees the stability of the world that he controls, Gittes is unable to conceive of the world in any way that is different than what he is familiar with. This disjunction is found throughout noir texts, expressing an anxiety over the rapidly changing nature of urban life. The people that make up the film's lower and middle classes-those who do not control the world nor enforce its order structure-are caught in the process of modernization as the project nears completion; even though the film takes place in the 1920 s, it represents how the automobile and eventual freeway system, coupled the vast amount of space in which to develop, initiates a new experience of space. The various sites shown in the film are isolated from each other, thus Cross is able to obscure his actions through the benefit of his world status and ability to manipulate 
each of the worlds contained within. Yet while Gittes is able to return to his normal daily life after the events of the film conclude, this option is not available to everyone that populates the noir version of Los Angeles. 


\section{CHAPTER 3}

\section{IF HE HOLLERS AND THE MINIMUM OF APPEARANCE}

Although the private eye offers a figure for interrogating fragmented urban space within LA noir through their very occupation, the city is populated by countless individuals who are directly confronted by their paucity of appearance. Within a world order structure that regulates appearance in accordance to the principles of post-industrial capitalist development, individuals are bound by factors beyond their control—race, class, education, geographical location. Despite what an individual may try to control, the relational network of the world that they find themselves existing in controls the intensity of their appearance and which aspects of their appearance come to the forefront. Worlds organized by capitalism are ordered so that "the disenfranchised, the poor, or any other multiples that exist on the edge of the void . . exist in the shadows of the transcendental of the world" (Shaw 436). Marginalized groups that are viewed as insignificant or a threat to the world's stability are pushed aside, ignored by those whose appearance is greater within the world.

Even early noir texts are guilty of ignoring the role that non-white citizens play within the structure of Los Angeles. Numerous critics have cited the lack of voices of racial others in noir fiction. ${ }^{4}$ Because it is a text that so forcefully confronts the existence

\footnotetext{
${ }^{4}$ For a full discussion of race in film noir, see Rabinowitz.
} 
of black Americans in Los Angeles, Chester Himes's 1945 novel If He Hollers Let Him Go provides critical insight into the minimalization of appearance enforced by the world's order structure. Marking a significant time of intense relations throughout the country, If He Hollers takes place during the industrial boom that occurred temporarily in Los Angeles during the World War II. To rapidly construct the ships needed in the war effort, employment was available for a wide range of individuals. As black Americans were hired, so too were economically depressed white migrants from the south. Because of this intermingling, these shipyards form a world where appearance is chaotically ordered based on the constantly shifting combination of individuals in the immediacy of the moment. Himes's novel is an incisive exploration of the constant shifting of appearance as one moves between the racially charged world of Los Angeles. Holding nothing back, Himes indicts the order structure of Los Angeles for the violent enforcement of its principles and ultimately concludes that the only point where racial others are granted anything more than the minimum appearance in Los Angeles is where they fully subordinate themselves to the control of white America.

\section{Himes and the Quality of Hurt}

Growing up in the Midwest, Chester Himes was no stranger to the realities of racism; however, the experience of Los Angeles affected Himes much more than his time spent in other cities because Los Angeles fell so short of its idealized version of progress. In the first volume of his autobiography, The Quality of Hurt, Himes does not hold back his feelings towards his few years living in Los Angeles:

Los Angeles hurt me racially as much as any city I have ever knownmuch more than any city I remembered from the South. It was the lying 
hypocrisy that hurt me. Black people were treated much the same as they were in an industrial city of the South. They were Jim-Crowed in housing, in employment, in public accommodations, such as hotels and restaurants (73).

Despite promises of scriptwriting work upon his arrival in the city, Himes was unable to succeed as a Hollywood writer in large part because of the overt racism of studio executives, and as a result he was forced to earn money as an industrial worker. World War II created such a large demand for unskilled workers in the shipyards along the Pacific coast that the hiring of black workers was much more common than in pre-war years. To take advantage of the availability of jobs, black and white uneducated workers flocked to Los Angeles from southern United States and its depressed industrial economy. As a consequence, race relations in the workplace were tense and openly unjust (Skinner 190). During his three years in Los Angeles, Himes worked twenty-three jobs, all but two of which were unskilled labor positions (Himes, QoH 74). Meanwhile, his wife found employment as a successful co-director of Los Angeles USOs and was respected by her white coworkers and members of the black middle class; Himes was humiliated by his inability to match his wife's success.

With the "mental corrosion" of racism experienced on the job leaving him "bitter and saturated with hate," Himes distilled his three years of anguish in Los Angeles into his first two novels, If He Hollers Let Him Go and The Lonely Crusade (QoH 76). Himes presents a dark vision of a Los Angeles where people of color are under constant threat of removal from society. If He Hollers follows four days in the life of Bob Jones, a wartime shipyard worker who wants nothing more than for his skin color to be ignored so that he would be judged according to his interior, not his exterior. As Jones is challenged by his coworkers and superiors on the job, and his wealthy fiancé and her parents at home, he 
comes to the realization that he will forever be judged by his exterior appearance. Jones struggles to come to terms with how whites and middle class people of color see his personhood. Reduced to his skin color, Jones sees his appearance stripped away, turning his racial anxiety into white hot rage. In If He Hollers, Himes presents a violent vision of Los Angeles as a battleground between whites and people of color. For a person like Jones, the only choices are to either actively resist racial oppression or accept his feelings of dehumanization as reality. Through his novel, Himes reveals the challenges of an individual trying to resist the organizing principles of the world(s) of Los Angeles, ultimately concluding that defiant non-identity with these principles results in the absolute negation of being.

\section{Racial Hate and the Minimum of Appearance}

At the time in which If He Hollers is set, Los Angeles is a major asset in the postPearl Harbor war effort, however it is also haunted by extreme racial prejudice exemplified by the removal of Asian-Americans to internment camps and the anti-Latino Zoot Suit Riots. The complex network of social, historical and political realities constitute a world that adds principles of racial superiority to the order structure of the world Los Angeles. For this reason, Jones is trapped within multiple worlds that use his race and class to minimize the intensity of his appearance. The different attitudes that Jones comes into contact with as he moves between worlds correspond to the different values enforced by the localized order structure. For example, at the shipyard at which Jones works, his being is granted a certain level of appearance based on an order structure grounded in production, but one that also holds onto racial distinction. Thus, Jones is 
caught in a tension between an increasing level of appearance based on his ability to add to the war effort and a default minimal level of appearance based on his race. Yet when Jones travels to the affluent west LA neighborhood of his girlfriend's parents, his appearance is determined by an organizing principle that lessens the importance of skin color itself while enforcing the social expectations for people of color that are maintained by those who support the world's order structure. Thus, while Jones's own appearance is determined by comparison to the transcendental order structure, his appearance is also structured in part by the presence of the white industrial workers from the Southern US and their attitudes towards race.

In many ways, Jones embodies much of what the Los Angeles myth meant for black Americans at the time. At the beginning of the novel, Jones is a promising upwardly mobile black man who has attended two years of college and could possibly return to study law. His leadership position at the shipyard grants him immunity from the draft, and even provides him enough money to purchase an automobile. Furthermore, he is dating the wealthy light-skinned daughter of a prominent black doctor, thus providing him with the stability to continue his social assent. However, the concessions that Jones has to make in order to follow his path bear down on his consciousness to the point that performing the passive black male that is granted the highest level of appearance possible for a black male at the time is almost unimaginable. His anxiety manifests as rage towards those that restrict his desire to be judged by the content of his being. As Jones loses his job and relationship over the course of the novel, his life spirals to the point of both literal and ontological disappearance. 
Himes's vision of Los Angeles is formed by his reaction to the two historical events of the Zoot Suit Riots and the attack on Pearl Harbor. Occurring during the summer of 1943 while Himes was living in Los Angeles, the Zoot Suit Riots refer to the weeks of violence between white servicemen and non-white "zoot suiters". Himes comments on these riots in his essay "Zoot Riots are Race Riots," published in The Crisis shortly after the events. In his article, Himes argues that the riots showcase "the reincarnation, or rather I should say the continuation of the vigilantes, the uniformed Klansmen . . of the United States navy, army and marine corps," who underwent a "great battle" that "defeated a handful of youths with darker skins" ("Zoot Riots" 200). These riots left Himes with the impression that the United States and its international policies were structurally racist, and the servicemen who attacked the zoot suiters were the enforcers of this racist system (Wilhite 129-130). The Zoot Suit Riots were a defining moment in Himes believing that force and perhaps even insurrection may be necessary for the sake of equality; this belief is expressed in If He Hollers through Jones's constant rage and violent fantasies. By placing the blame on the United States government instead of the servicemen who actually committed the crimes, Himes denies that the riots are aberrant. The servicemen represent an ever present threat to people of color, especially those who refuse to hide in society's shadows; in the Los Angeles of Himes's experience, there is no room for people such as him because there are other beings within the world who enforce an organizing principle that denies his appearance in that world.

The social climate that allows violence like the Zoot Suit Riots is expressed through the changing threat of violence that Jones experiences as he travels through distinctly segregated areas. Keith Wilhite argues that the Zoot Suit Riots inform the 
intense geographical segregation that is present in Himes's vision of Los Angeles. Jones "map[s] a pattern of segregation in Los Angeles with each street he turns down and each district he navigates," always conscious that "men like Jones pass through their own peril" (134). Wilhite concludes that violence and geography are inseparable for Himes:

What Jones' narration "maps" for the reader, then, is a metro-region that seems always on the verge of revolution, and we are meant to see that threat of violence as inseparable from the entrenched fluidity of Los Angeles's segregated geographies. . Jones is free to cross boundaries and move through public spaces, but only in a way that calcifies his conspicuous presence as a threat to the tenuous equilibrium of racial tension held in check by segregated patterns of development (139).

Thus, while Jones travels through the segregated worlds of Los Angeles, his appearance is affected by the threat of violence within that world. When racist aggression is rewarded by the transcendental order structure of that particular world, Jones faces a greater threat of violence to his being than he would in a world like that of the affluent black west Los Angeles. In this world, the order structure grants appearance to the qualities that highlight Jones's potential as a successful black leader.

The attack on Pearl Harbor further heightened Himes's fear of violence and complete segregation for the non-white members of Los Angeles. After Pearl Harbor and during the use of internment camps for anyone appearing to be a Japanese American, anti-Asian racism reached its apex. Knowledge of these internment camps leads Jones to fear that black Americans could easily experience the same separation from society. Even though race had "never really gotten [him] down," Jones's anger manifests once he experiences the "crazy, wild-eyed, unleashed hatred that the first Jap bomb on Pearl Harbor let loose in a flood" (IHH 3-4). This wave of racial hatred, coupled with a very real threat of violence after the Zoot Suit Riots, is a concrete instantiation of a 
transcendental organizing principle that must remove anything that is seen as a threat to that world. In identifying with persecuted Latino and Asian Americans, Jones feels his own appearance within the world diminishing; he is present in a world that does not want him to be there, and thus fears the threat to his very being.

The Pearl Harbor bombing has a strangely positive effect for Jones as well because it initiates the Pacific front of the war, sparking the industrial boom that allows for a person of color like Jones to appear as a valuable contributor to production instead of as an undesired non-white. As long as Jones can prove his value as a shift leader who will quiet racial tension, he is granted a higher level of appearance within the world that contains the coastal shipyards. Because of his position at the Atlas shipyard, Jones is also able to defer his draft status and afford his own vehicle—his lone sign of middle class status. Without this position, Jones would certainly be forced into the military, serving the institution that he strongly stands against. For this reason, any threat to his job serves as a threat to Jones's life.

Jones's refusal to even partially identify with an order structure that is so clearly unjust makes it inevitable that he will come into conflict with those who do identify with that world. On the first day that we follow Jones on the job, he loses his lead position because a white female worker named Madge refuses to help Jones's all-black outfit; his responding outburst at Madge fails to match the passive role expected by the white leaders who intend for Jones to be an example against racial antagonism. The fear and anger that consumes Jones after his demotion further alienates Jones from both the whites and non-whites around him as he searches for any action that might interrupt his current circumstance. The fact that Jones loses his position for simply speaking up against a 
white woman who refuses to perform her work duties with a black outfit connects Jones's struggle to that of other non-whites in Los Angeles. When Jones is demoted, he experiences a sudden "crazy, scared feeling ... like the Japanese getting pulled up by the roots" (IHH 30). Identifying even more with the Asian population than before, Jones allows for the feelings of fear and uprootedness to guide his actions. When he is attacked by a coppersmith during a break-time game of dice, Jones hunts the man down, opens a knife from his pocket, and considers stabbing the man in order to make him feel "as scared and powerless and unprotected as I felt every goddamned morning I woke up." Jones "wanted him to know how it felt to die without a chance; how it felt to look death in the face and know it was coming and know there wasn't anything he could do but sit there and take it like I had to take it" (IHH 35). Jones hesitates, waiting until he can follow the man home instead. After doing so, Jones thinks twice about his actions: "I didn't have to kill him now . . I could kill him at any time; I could save him up for killing like the white folks had been saving me up for all these years" (IHH 44). Enjoying the power that he possesses over the coppersmith, Jones gains some sense of agency knowing that he is capable of returning the violence that he so strongly fears. As he senses his appearance waning through the events of his workday, he searches for the action that will shift his future in any direction other than the path it is headed down. While the options that present themselves to Jones are even bloodier than state violence, they appear as the only possible actions because within this world, transgression seems to be the only action that can achieve Jones's goal of being seen by the world around him even though his visibility would be only temporary. 


\section{Threatened Appearances}

Although Jones's job provides him with protection from the draft, he perceives the bigger threat to be the loss of his vehicle because his vehicle provides him a source of pride; Jones's ' 42 Buick Roadmaster is the only sign that he has achieved any semblance of the success that Los Angeles promises. Furthermore, just as with Marlowe and Gittes, Jones's vehicle allows him to travel across the many geographical boundaries that are carved into the city. Throughout the course of the novel, Jones travels through the diverse neighborhoods of southern LA, the coastal shipyards, and the predominantly white upper-class neighborhood of Beverly Hills. He expresses the power that he feels his vehicle gives him: "I had a '42 Buick Roadmaster I'd bought four months ago, right after I'd gotten to be a leaderman, and every time I got behind the wheel and looked down over the broad, flat, mile-long hood I thought about how rich white folks out in Beverly couldn't even buy a new car now and got a certain satisfaction" (IHH 10). Like Walter Mosley's African American detective Easy Rawlins, who is a product of the same time period as Bob Jones, vehicle ownership provides a mark of class ascendency for midtwentieth century African Americans-a sign that, in some ways, the Los Angeles myth is possible. The thought that Jones could lose his car now that he has lost his position threatens his dignity more so than losing his job entirely: "I'd lose my car. I think that was what made me decide that my pride wasn't worth it. My car was proof of something to me, a symbol. But at the same time I didn't analyze the feeling; I just know I couldn't lose my car even if I lost my job" (IHH 30-31). Lynn Itagaki argues that Jones's car "becomes a vehicle for physical transgression; Bob challenges white drivers in duels over space and superiority along the highways - a metonymic expression of the larger hostility 
and competition of social and economic racism" (73). As long as he is within the vehicle, Jones asserts his class ascendancy while attempting to hide his skin color behind the wheel—speed obscures anyone's identification of his skin color. Within his car, Jones structures his own world, one where he is able to compete over the roadways with white drivers, and share an equal status with others who are on the roads. However, this mindset fails as he tries to hide from police but is found when his vehicle is stopped at a light in a white neighborhood. Without sufficient fuel to rush away, the vehicle is transformed "into a waiting place, a mere rest-stop that reveals the futility of Bob's assimilation and migration" (73). Inevitably, Jones's Buick is the last site that he inhabits as a free man after Madge falsely accuses him of rape. Ultimately, Jones cannot contain himself within his vehicle; the world outside of his car catches up to him, absorbing him back into the world of white Los Angeles.

Jones's racial frustration is compounded by his relationship with Alice, whose family shares the predominant middle class perspective of the period that holds that whites are trying to help blacks rise up the social ranks and blacks need to be gracious in accepting their help. Alice's mother is elated that Bob has expressed interest in returning to school in order to "join the ranks of Negro professionals" (IHH 51). When Bob mentions wanting to "get even with the white folks," Alice's mother chides, "You mustn't think in terms of trying to get even with them, you must accept whatever they do for you and try to prove yourself worthy to be entrusted with more ... We've got to earn our equality. We've got to show them that we're good enough, we've got to prove it to them" (IHH 51-52). Alice's mother expresses a worldview held by most of her class, regardless of race. In fact, Alice's mother makes the same appeal as Jones's superiors at work when 
they express their surprise at Jones for allowing one person's racism to ruin the "gift" of a supervisor's position (IHH 29).

The conflict that pits Jones against Alice and her family highlights the larger issue of Jones's rapidly disappearing appearance in the worlds in which he finds himself living. Within the worlds that Jones inhabits, he is expected to be passive and remain in the shadows - he ought to be content with a minimum level of appearance within the society. However, Jones cannot accept this state of affairs because he demands basic equality. When the transcendental order structure of a world is formed by the relationship between beings, one's appearance within the world is largely out of one's control if one is not a part of the set of beings who hold the most influence on world formation and modification. Alice attempts to get this message across to Bob: "I don't want to be pulled down by a person who can't adjust himself to the limitations of his race" (IHH 97). In Alice's mind, the ways in which race fits in with the order structure has been reified; for her, the socially rewarded path involves total acceptance of the racist 'truth' of midcentury Los Angeles. However, Jones cares less about social rewards, and as much as he struggles to accept her message, he cannot come to terms with this system. Within the affluent black community, Jones knows that he will only be seen for his potential as a model black citizen, and for the white community, he will be seen first for his race; his practical worth as a laborer is only secondary. Jones attempts to talk himself into believing in the upward mobility that has been preached to him, but he knows that, if he could accept this, he would "wake up someday and say to hell with it, didn't want to be the biggest Negro who ever lived . . because deep inside of me, where white folk couldn't see, it didn't mean a thing" (IHH 153). Rather than force himself into following 
a role that he does not desire, he recognizes that he is trapped in a world in which he does not belong. If his inherent equality with all people is not recognized, then "there'd never be anything in this country for [him] anyway" (IHH 154). In his particular place and time, Jones's being cannot exist outside of these relations; he is indexed to the world in as much as he is a localized being within a determined space (Shaw 437).

In recognizing that he will always possess a minimal appearance, Jones comes into direct conflict with the institutional powers that enforce the social ordering structure. Targeted against the objective enforcers of the world's transcendental order, the violent fantasies of murder and rape that have been the critical focus of Himes scholarship are an expression of Jones's anxiety over his disappearing identity. Badiou's concept of the envelope once again provides critical insight in understanding how Jones is forced to the margins of this world. While there are limitless forms of multiples that the envelope may take depending on the structure of the specific world, in the case of Los Angeles - and any determinate physical location organized by a social order - the envelope can identify those beings who actively order appearance in accordance with the transcendental order structure, such as the serviceman involved in the Zoot Suit Riots. These beings are not the envelope themselves; instead, in this case, the envelope is the social order that results from the aggregation of the individual actions taken by those most identical with the transcendental order structure. Thus, the individuals that Jones comes into contact with are the beings who, in varying degrees, support the racial order that has stabilized in wartime Los Angeles. The world's order structure promises upward mobility and the achievement of the idea behind the sunshine myth, but the absence of any real content to this idea places those who recognize this fact in direct opposition to the world. 
In the end, Jones finds himself negotiating two worlds with two dominating order structures. In one context, when Jones can no longer fulfill his role at work, he faces an increasingly diminishing appearance because his worth to the war manufacturing effort, derived from his symbolic purpose as an interracial peacekeeper, is no longer valuable. Jones struggles to and ultimately gives up on embracing the predetermined path of respectability that the black middle class community expects him to accept. Jones's failures in both of these worlds demonstrates how Himes's fiction speaks to the negation experienced by individuals as they are forced into the shadows of the worlds they inhabit. As Christopher Breu argues, "Himes's fiction suggests that objectification and negation are the experience of the marginalized at sites of intersection in American culture" (146). The non-identity between how Jones views himself within the world and how others view him within the world leads to what Franz Fanon refers to as the "crushing objecthood" of racism.

Unlike many other examples of noir literature and film, Himes places the reader within the psychological interior of the protagonist through dream sequences and violent fantasies. By having access to the raw consciousness of Jones, the reader is able to penetrate appearance when all others are unable to do so. This interiority is significant in understanding the vision of Los Angeles that Himes presents because it allows for him to express his own anxiety that gestated throughout his four years in Los Angeles. In hardboiled detective fiction, the superficiality of characters' intentions results from the lack of any interior psychological depth; the struggle for wealth in The Maltese Falcon and the Sternwood daughters' illicit activities in The Big Sleep stem from their restlessness, not some deep psychological need. In contrast, Himes shows that in spite of Jones's status as 
an object for the gaze of whites and middle class blacks there is a subject within the exterior. While it proves impossible for others to penetrate Jones's appearance, Himes expects the reader to understand the crushing feeling of being reduced to an object among subjects. In this way, the text follows Chandler and Wilder's original ending to Double Indemnity, where the protagonist's end is experienced by the viewer so that we experience the violence of the system that ultimately negates their being. Given the choice of jail or service in the military by the judge who tries him for Madge's alleged rape, Bob Jones is sent to war alongside two Latino men. The judge believes that he is giving the men a break by enforcing justice while not actually incarcerating the men. In fact, for the world in which Jones finds himself, he is guilty_guilty of resisting the world's organizing principle. He is a threat to the stability of the world, and for that reason must be removed from it. He disappears as we are led to assume that Jones will be killed because there is no place for him to return to in that version of the United States.

As an expression of the experience of racial oppression, If He Hollers Let Him Go contributes to this study of the ontology of noir representations of Los Angeles by incisively depicting the daily experiences of a single man who struggles to assert his appearance to the worlds in which he inhabits. The fact that the entire event of the novel takes place over only four days testifies to the speed at which appearance can be reordered for those who exist at the margins of the world. Within this short period, Jones goes from an upwardly mobile, hopeful supervisor complete with middle class necessities like his automobile to a draftee being shipped away to fight in the Pacific war front. The fact that the novel assumes that Jones will not make it back from the war further intensifies Himes's indictment of the order structure of Los Angeles. Without the 
principles of justice and racial equality being raised to the status of truth within the order structure, the world of Los Angeles appears as a world not worth living in to Himes. Despite Jones's effort to display his interior self without the filter of race, he is only judged by those elements of his body that are privileged by the world in which he lives. Without violently inserting his being into the state of the world, Jones is left with no action that can alter his course - he is a body removed from the world, no longer visible to the rest of those who make up Himes's depiction of Los Angeles. 


\section{CONCLUSION}

In the versions of noir Los Angeles discussed in this thesis, the sunshine myth frames individual characters as they struggle within the new structure of decentralized post-industrial urban space. While masking the underlying ideology of capitalism that guides the development of Los Angeles, the sunshine myth promotes the ends of wealth and success that the city's early rhetoric inserted into the world as organizing truths. LA noir texts represent the process through which the city's order structure takes particular individuals whose identities do not correspond with the world's truth and orders appearance at a minimal level at the margins of the world. Badiou's ontology provides a critical apparatus for reading noir representations of Los Angeles because his approach allows one to focus on the relationship between objects within a determinate space, as opposed to the body of noir scholarship that isolates the subjective existential anxiety of individual noir characters. However, by applying Badiou's system of thought to LA noir texts, one notes that the fictional worlds appear absolutely unchangeable. In the cases of Philip Marlowe, Jake Gittes and Bob Jones, the characters' stories end with defeat as the world reestablishes its previous status quo. The individual, isolated in space, fails at defending a truth that is absent from Los Angeles's organization, thus the possibility of radical change within the world appears bleak. In fact, this argument runs throughout Badiou's ontology as he argues that global capitalism has become the background 
ideology spread throughout the infinite worlds that form human relations (Zizek 397). As Peter Hallward notes, "[T]he domination of its state is effectively absolute ... It is precisely this indetermination that ensures conformity or obedience from the (classified, divided ....) members of the situation" (Introduction, ix). Slavoj Zizek challenges Badiou for this very "renaturalization of capitalism in the guise of reduction of capitalism to an omnipresent background of political struggles" (405). Despite this analysis of globalized capitalism, Badiou maintains the possibility of a radical break from a world - a reorganization of a specific site around a fundamentally new order structure.

In response to the pervasiveness of contemporary capitalism, Badiou commits to a politics that is based on the possibility of locally-situated political struggles that are "held together through multiple and sometimes competing wills, and whose struggle, quite irrespective of the 'identity' of its subjects, has the potential to enter into almost any walk of life" (Barker xiv). This redefinition of politics does not reduce individuals in the same way as identity politics, but accounts for the particularities of bodies identified through the infinite permutations of the set of inconsistent multiples that forms one's personhood. Furthermore, Badiou's idea of politics is one that prescribes "a possibility in rupture with what exists" (Metapolitics, 24). By dedicating one's self to a truth that is absent from a world, and remaining dedicated to that truth, one grasps at complete reorganization, and not just modification, of a worlds structure. Political work, according to Badiou, ought to be "concerned with people or situations who are not so much invisible or unseen as under-seen or mis-seen—oppressed and exploited, rather than simply excluded" (Hallward "Order and Event," 117). By focusing on localized politics and those who appear as marginal figures within that world, Badiou argues that those who live at the 
edges are the very agents who are able to interrupt the order of the world, for they are most capable of initiating the radical break from the world's established order structure.

Marginalized persons escape the containment of the world through the process of asserting a new truth that was absent from the previous state of the world, thus maintaining the possibility of "creating new worlds by presenting a previously 'inexistent' multiple" (Shaw 432). Individuals attempt to defend truths that are absent from the world in the face of an order structure that actively tries to transform resistance into modification instead of complete transformation. By developing a theory of the 'site,' Badiou articulates a process by which a world's order structure is reorganized by those who exist on the margins, thus providing a framework for rethinking the unflinching inevitability of failure in LA noir. Opening up the possibility of change within a world, the site represents the emergence of the "clandestine, autonomous and forbidden from the world" (Shaw 437). That which formerly did not appear within the world-the inexistent - appears at the site of an event, forming a singular autonomous world indexed to its own novel set of truths defended by the individuals within that site.

The widespread suspicion towards the possibility this radical break from the postindustrial capitalist world of Los Angeles can be found throughout noir representations of the city. Individuals try to reorganize the worlds in which they find themselves, yet in every case the protagonist is left with the disquieting realization that the world's structure enforces its order without fail. In Chinatown, Gittes loses both the woman he was trying to protect while Noah Cross slinks away just as powerful as before; Bob Jones is shipped away from Los Angeles in If He Hollers, removed from the world that produced so much psychological hurt. The possibility of disrupting the world of the status quo appears 
briefly in many noir texts, only to be denied at the conclusion. Gittes's failure to defend the truth of justice reveals his inability to restructure the world in which he finds himself. By supporting the truth of justice abstracted from the world's particular politics, Gittes defends a truth that is separated from the determinate space populated by particular bodies working against this defense. His desperate try at exposing Cross to the city's policemen at the conclusion of the film attempts reorganization of the location of Chinatown, yet his isolation leads to failure. Additionally, Bob Jones's level of appearance quickly diminishes as his value as a worker is threatened. His desire to kill those who abused him for his skin color expresses his demand for appearance within the world even though recognition in this way would require him to appear as the violent fantasy image he imagines all whites hold in their minds. The abstract idea of equality appears empty to Bob because it is separated from his particular position as an educated Black industrial worker. He cannot wait for a day when the generic truth is realized and cannot defend the truth as an isolated individual, so his existence is non-identical with the world in which he lives. Bob's urge to violently assert his existence within the world reveals his desire to be seen as an equal agent within it, yet this singular action cannot spark a radical change in the world's structure because it is not an action that defends the truth; murder might reorganize a site around fear of Jones, but this site is not organized in fidelity to racial equality. In both of these texts, the protagonists struggle to insert new truths into the world - truths that ring empty among the rest of those who populate the world.

Thus, noir texts pose a significant question regarding an individual's commitment to asserting a truth and a world's reaction to the individual assertion. For Badiou, 
defending a truth requires an ethical commitment to that truth's generic content. For instance, the specific acts of Noah Cross in Chinatown lead Gittes to the generic commitment towards political justice that is not reducible to the situation even though the truth generates from a particular act (Critchley 42). In Ethics, Badiou argues that when one fails to remain committed to a truth-like justice in Chinatown or racial equality in If He Hollers-one commits an act of betrayal (79). In fact, the cynical undercurrent throughout LA noir texts results from the aftermath of realizing that some truth is absent from the world—the self-deception that the truth "never existed." Thus, one "rall[ies] to opinion's perception of this point-opinion, whose whole purpose, in the service of interests, is precisely this negation [of the truth]" (79). However, the isolation experienced by these characters uncovers the contribution that LA noir texts make towards an understanding of Badiou's ontology. In the decentered spaces represented in LA noir texts, individuals cannot defend a truth within a world that is so forcefully unified around an opposing order structure. Thus, noir texts reinforce the emergence of an ideological system of post-industrial capitalism experienced by individuals through the geography of decentered urban space.

Contemporary Los Angeles no longer seems like the anomaly that it was during the majority of the $20^{\text {th }}$ century. Now connected with other post-industrial metropolises throughout the globe, LA is a fully developed, globalized city. Just as the freeway radically shaped the development of Los Angeles in the 1930s and 40s, the city is in the midst of a worldwide shift in "the human experience of space, distance, and time" caused by "high speed information, media and transportation technologies; the transnational modes of production and consumption; the accelerated flow of people, capital, goods, 
information, and entertainment" (Lee 503). If automobiles ushered in the physical experience of speed and modified the way that individuals relate to their geographical environment, then the contemporary equivalent proves all the more life-altering as products, people and information move throughout the globe with Los Angeles functioning as one of the many focal points in the movement.

The development of an information-based economy supports the humanist vision of progress towards a cosmopolitan world that erases difference with the goal of constructing an idea of a universal humanity. Recent theorists have questioned the effectiveness of the "we" posited by the rhetoric of universalism that forms "the heart of unidirectional deployments of . . Eurocentrism, colonialism, imperialism, racialism, nationalism, sexism, paternalism, [and] heterosexism" while being supported by "the discursive and material coerciveness of a few who presume to speak for all" (Lee 504). Such universalism reduces the particularity of bodies and, by assuming the possibility of an 'end' to unequal representation, posits an abstract subject that populates a new global village "occupied by First world consumers who rationalize their privileged mobility and consumption as responsible acts of global citizens . . . oblivious to their own role in the relations of power" (Lee 507). By stripping away the particularities that accompany determinate bodies, universalism erases "the contingencies of time and space, history and location" while "elid[ing] its operations of dominations, projecting instead the appearance of being democratic" (Palumbo-Liu 188). Conceived in this way, the rhetoric of universalism ignores the particular differences that determine a body's appearance in the world; however, the differences still affect an individual's level of appearance. Positing an abstract human subject does violence to the individuals who are excluded because of 
individual difference, thus ignoring the very elements of identity that structures one's relationship to the world.

The ontological investigation of worlds offered by LA noir texts demonstrates how the experience of living within urban space has challenged writers and artists throughout the development of modernity. The process of the completion of industrialization and the transition to information-based economies within early Los Angeles marks a popular attempt to express the uncertainty stemming from being there. With an idealized sunshine version of Los Angeles functioning as the desired goal of the worlds that make up the city, its ordering structure levels appearance based on one's ability to help the city move towards that goal. However, these operations ignore the particular experiences of individuals and the specific differences that make up each person. The anonymity provided by the new centerless city may promote individual isolation, but the relational network offered by Badiou's ontology sheds light on the process in LA noir by which individuals remain trapped in a relational network through which particular identity, experiences, and desires vary in appearance, entangled in any of Los Angeles's many noir worlds. 


\section{REFERENCES}

Babener, Liahna K. "Raymond Chandler's City of Lies." Los Angeles in Fiction. Ed. David M. Fine. Revised ed. Albuquerque: U of New Mexico P, 1995. 127-149. Print.

Badiou, Alain. Logics of Worlds. Trans. Alberto Toscano. London: Continuum, 2009. Print.

---. Ethics: An Essay on the Understanding of Evil. Trans. Peter Hallward. London: Verso, 2001. Print.

---. Metapolitics. Trans. Jason Barker. London: Verso, 2005. Print.

Barker, Jason. Introduction. Metapolitics. By Alain Badiou. London: Verso, 2005. Print. Benedetto, Robert. "The Two Chinatowns: Towne's Screenplay vs. Polanski's Film." Creative Screenwriting 6.6(1999): 49-54. Print.

Breu, Christopher. Hard-Boiled Masculinities. Minneapolis: U of Minnesota P, 2005. Print.

Chandler, Raymond. The Big Sleep. New York: Vintage Crime/Black Lizard, 1992. Print.

---. The Little Sister. Later Novels and Other Writings. New York: Library of America, 1995. 203-416. Print.

Chinatown (Special Collector's Edition). Dir. Roman Polanski. Perfs. Jack Nicholson, Faye Dunaway, John Huston. 1974. DVD. Paramount, 2007. 
Critchley, Simon. Infinitely Demanding: Ethics of Commitment, Politics of Resistance. London: Verso, 2007. Print.

Davis, Mike. City of Quartz: Excavating the Future of Los Angeles. London: Verso, 2006

-.-. "Bunker Hill: Hollywood's Dark Shadow." Cinema and the City: Film and Urban Societies in a Global Context. Ed. Mark Shiel and Tony Fitzmaurice. Oxford: Blackwell P, 2001. 33-45. Print.

Dimendberg, Edward. Film Noir and the Spaces of Modernism. Cambridge: Harvard UP, 2004. Print.

DoCarmo, Stephen N. "Postmodernist Quietism in Polanski's Chinatown and Lynch's Mulholland Drive." The Journal of Popular Culture 42(2009): 646-662. Print.

Duffy, Enda. "On his book The Speed Handbook: Velocity, Pleasure, Modernism." Rorotoko. Rorotoko, 23 May 2010. Web. 16 November 2011.

Farish, Matthew. "Cities in Shade: Urban Geography and the Uses of Noir." Environment and Planning D: Society and Space 23(2005):95-118. Print.

Fine, David M. Imagining Los Angeles: A City in Fiction. Albuquerque: U of New Mexico P, 1986. Print.

--.. Introduction. Los Angeles in Fiction. Ed. David M. Fine. Revised ed. Albuquerque: U of New Mexico P, 1995. 1-26. Print.

Fogelson, Robert M. The Fragmented Metropolis: Los Angeles 1850-1930. Cambridge: Harvard U P, 1967. Print.

Gilmore, Richard. "The Dark Sublimity of Chinatown." The Philosophy of Neo-Noir. Ed. Mark T. Conard. Lexington: U P of Kentucky, 2007. 119-136. Print. 
Hallward, Peter. "Order and Event: On Badiou's Logics of Worlds." New Left Review 53(2008): 97-122. Print.

--.. Introduction. Ethics. By Alain Badiou. London: Verso, 2005. Print.

---. Badiou: A Subject of Truth. Minneapolis: U of Minnesota P, 2003. Print.

Hammett, Dashiell. Red Harvest. Dashiell Hammett: Five Complete Novels. New York: Avenel Books, 1980. 1-142. Print.

Hausladen, Gary J. and Paul F. Starrs."L.A. Noir" Journal of Cultural Geography 23(2005):43-69. Print.

Heise, Thomas. "'Going Blood Simple like the Natives': Contagious Urban Spaces and Modern Power in Dashiell Hammett's Red Harvest." Modern Fiction Studies 51.3(2005): 485-512. Print.

Himes, Chester. If He Hollers Let Him Go. Cambridge: Da Capo Press, 2002. Print. ---. "Zoot Suit Riots are Race Riots." Crisis July 1943: 200-222. Print.

-... The Quality of Hurt: The Autobiography of Chester Himes. Garden City, NY: Doubleday, 1972. Print.

Howell, Philip. "Crime and the City Solution: Crime Fiction, Urban Knowledge, and Radical Geography." Antipode 30.4(1998): 357-378. Print.

Itagaki, Lynn M. "Transgressing Race and Community in Chester Himes's If He Hollers Let Him Go." African American Review 37(2003):65-80. Print.

Jameson, Fredric. "The Synoptic Chandler." Shades of Noir: A Reader. Ed. Joan Copjec. London: Verso Books, 1993. Print.

Klein, Norman M. The History of Forgetting: Los Angeles and the Erasure of Memory. London: Verso, 2008. Print. 
Lee, Sue-Im. "'We are Not the World': Global Village, Universalism, and Karen Tei Yamashita's Tropic of Orange." Modern Fiction Studies 53(2007): 501-527. Print. Lehan, Richard. "The Los Angeles Novel and the Idea of the West." Los Angeles in Fiction. Ed. David M. Fine. Revised ed. Albuquerque: U of New Mexico P, 1995. 29-41. Print.

Marling, William. The American Roman Noir: Hammett, Cain, and Chandler. Athens: U of GA P, 1995. Print.

McCann, Sean. Gumshoe America: Hard-Boiled Crime Fiction and the Rise and Fall of New Deal Liberalism. Durham: Duke UP, 2000. Print.

McClung, William. Landscapes of Desire: Anglo Mythologies of Los Angeles. Berkeley: U of California P, 2000. Print.

Naremore, James. More Than Night: Film Noir and Its Contexts. Berkeley: $\mathrm{U}$ of California P, 1998. Print.

Palumbo-Liu, David. "Universalism and Minority Culture." Differences. 7.1(1995): 188208. Print.

Polanski, Roman. Roman. New York: Morrow, 1984. Print.

Rabinowitz, Paula. Black \& White \& Noir: America's Pulp Modernism. Columbia UP, 2002. Print.

Raczkowski, Christopher T. "From Modernity's Detection to Modernist Detectives: Narrative Vision in the Work of Allan Pinkerton and Dashiell Hammett." Modern Fiction Studies. 49(2003):629-658. Print. 
Shaw, Ian Graham Ronald. "Sites, Truths, and the Logics of Worlds: Alain Badiou and Human Geography." Transactions of the Institute of British Geographers. 35(2010): 431-442. Print.

Shetley, Vernon. "Incest and Capital in Chinatown." MLN. 114.5 (1999): 1092-1109. Print.

Skinner, Robert E. "Streets of Fear: The Los Angeles Novels of Chester Himes." Los Angeles in Fiction. Ed. David M. Fine. Revised ed. Albuquerque: U of New Mexico P, 1995. 227-238. Print.

Soja, Edward W. and Allen John Scott. "Introduction to Los Angeles: City and Region." The City: Los Angeles and Urban Theory at the End of the Twentieth Century. Ed. Soja and Scott. Berkeley: U of California P, 1996. 1-21. Print.

Towne, Robert. "Chinatown-A Screenwriter's Eulogy for Los Angeles." Architectural Digest. 57.4(2000): 64-68. Print.

--.. Chinatown. Script. New York: Faber and Faber, 1998.

Walker, Casey. "Keys to the City." Los Angeles Review of Books. Los Angeles Review of Books, 30 May 2011. Web. 16 November 2011.

Walton, John. "Film Mystery as Urban History: The Case of Chinatown." Cinema and the City: Film and Urban Societies in a Global Context. Ed. Mark Shiel and Tony Fitzmaurice. Oxford: Blackwell P, 2001. 46-58. Print.

Weinstein, Richard S. "The First American City." The City: Los Angeles and Urban Theory at the End of the Twentieth Century. Ed. Edward W. Soja and Allen John Scott. Berkeley: U of California P, 1996. 22-46. Print. 
Wilhite, Keith. "Mapping Black and Brown L.A.: Zoot Suit Riots as Spatial Subtext in If He Hollers Let Him Go." Arizona Quarterly. 66(2010): 121-148. Print.

Zizek, Slavoj. In Defense of Lost Causes. London: Verso, 2008. Print. 


\section{CURRICULUM VITAE \\ Jacob Goessling 155 William St \\ Louisville, KY 40206 \\ jacob.goessling@gmail.com}

\section{Education:}

University of Louisville, Louisville, Kentucky

Master of Arts, English

Graduated December 2011

Thesis: "Noir Ontology: Existing in the Fragmented Urban Spaces of Los Angeles"

Bachelor of Arts, Philosophy

Graduated May 2007, Summa Cum Laude \& University Honors Scholar

Thesis: "Emancipatory Art in the Age of the Culture Industry"

Awards:

Richard Campbell Smith Award for Demonstrating Excellence in Philosophy, 2007

\section{Conference Experience:}

Louisville Conference on Literature and Culture since 1900, February 2010

"Not a Tourist ... It's Called Research": Community, Method, and Representation in Desert Blood

\section{Presentation Experience:}

Philosophy Co-Think, University of Louisville, Louisville, KY

"Theodore Adorno and Walter Benjamin: A Radical Critique of Art," February 2007

\section{Classes Taught:}

English 101-Introduction to College Writing

English 102-Advanced College Writing

\section{Extracurricular Activities:}

Philosophy Grant Committee (January 2007-January 2008)

Position: Member of six person committee

Description of Responsibilities: Constructing a culturally diverse Introduction to Philosophy course which meets the CD course requirements at the University of Louisville, reading and evaluating all possible course materials, evaluating materials 
based on depth of content and ability to be taught, developing non-traditional teaching methods, and writing the course proposal to be submitted to the department review board.

Phi Sigma Tau, Philosophy Honors Society (2004-Present)

Position: Vice-President (Fall 2005 - Fall 2006), Secretary (Fall 2006- Spring 2007) Description of Responsibilities: Conducting group meetings, organizing student outreach and membership drives, organizing student led events within the Philosophy department, organizing monthly Co-Think events, documenting all group meetings, and communicating with the national head office of Phi Sigma Tau. 